\title{
Phycologia Phycologia
}

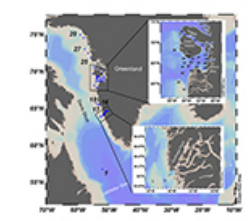

\section{Amphidomataceae (Dinophyceae) in the western Greenland area, including description of Azadinium perforatum sp. nov.}

\author{
Urban Tillmann, Stephan Wietkamp, Bernd Krock, Anette Tillmann, Daniela \\ Voss \& Haifeng Gu
}

To cite this article: Urban Tillmann, Stephan Wietkamp, Bernd Krock, Anette Tillmann, Daniela Voss \& Haifeng Gu (2020) Amphidomataceae (Dinophyceae) in the western Greenland area, including description of Azadinium perforatum sp. nov., Phycologia, 59:1, 63-88, DOI: 10.1080/00318884.2019.1670013

To link to this article: https://doi.org/10.1080/00318884.2019.1670013

View supplementary material $[\nearrow$

\section{曲 Published online: 02 Dec 2019.}

Submit your article to this journal $\pi$

Џ Article views: 62

Q View related articles $₫$

View Crossmark data $\nearrow$ 


\title{
Amphidomataceae (Dinophyceae) in the western Greenland area, including description of Azadinium perforatum sp. nov.
}

\author{
Urban Tillmann $^{1}$, Stephan Wietkamp ${ }^{1}$, Bernd Krock ${ }^{1}$, Anette Tillmann ${ }^{1}$, Daniela Voss ${ }^{2}$, and Haifeng Gu (i) ${ }^{3}$ \\ ${ }^{1}$ Alfred-Wegener-Institute, Helmholtz Centre for Polar and Marine Research, Am Handelshafen 12, Bremerhaven, D-27570, Germany \\ ${ }^{2}$ Institute for Chemistry and Biology of the Marine Environment (ICBM), Carl von Ossietzky Universität Oldenburg, Schleusenstraße 1, Wilhelmshaven, \\ $D$-26382, Germany \\ ${ }^{3}$ Third Institute of Oceanography, Ministry of Natural Resources, Xiamen, 361005, China
}

\begin{abstract}
Azaspiracids (AZA) are lipophilic marine biotoxins associated with shellfish poisoning which are produced by some species of Amphidomataceae. Diversity and global biogeography of this family are still poorly known. In summer 2017 plankton samples were collected from the central Labrador Sea and western Greenland coast from $64^{\circ} \mathrm{N}$ (Gothaab Fjord) to $75^{\circ} \mathrm{N}$ for the presence of Amphidomataceae and AZA. In the central Labrador Sea, light microscopy revealed small Azadinium-like cells (9200 cells ${ }^{-1}$ ). Clonal strains established from plankton samples and scanning electron microscopy of fixed plankton samples revealed at least eight species of Amphidomataceae: Azadinium obesum, Az. trinitatum, Az. dexteroporum, Az. spinosum, Az. polongum, Amphidoma languida, Azadinium spec., and a new species described here as Azadinium perforatum sp. nov. The new species differed from other Azadinium species by the presence of thecal pores on the pore plate. All samples, including cultured strains, filtered seawater samples, and solid phase adsorption toxin tracking (SPATT) samplers deployed during the expedition in a continuous water-sampling system (FerryBox), were negative for AZA. DNA samples and PCR assays were positive for Amphidomataceae from most stations, whereas species-specific assays for three toxigenic species were rarely positive (two stations for Az. poporum, one station for Am. languida). The results highlight the presence of Amphidomataceae in the area but the lack of toxins and low abundance of toxigenic species currently indicate a low risk of toxic Amphidomataceae blooms in Arctic coastal waters.
\end{abstract}

\section{ARTICLE HISTORY}

Received 16 May 2019

Accepted 17 September 2019

Published online 02

December 2019

\section{KEYWORDS}

Amphidoma; Azaspiracids New species; Subarctic

\section{INTRODUCTION}

Biodiversity and biogeography research of high latitude phytoplankton have a long history, starting with the first exploratory expeditions in the mid-19th and early twentieth century (Brandt \& Apstein 1908; Cleve 1873; Cleve \& Grunow 1880; Ehrenberg 1843; Gran 1929; Grontved \& Seidenfaden 1938; Lebour 1925). Extensive lists of plankton species from these survey reports are still the basis for contemporary taxonomic research in the Arctic. Such historical work and also more recent taxonomic studies are needed as an indispensable baseline in order to fully evaluate potential change in species diversity, and distribution and community composition in the area. This is of special importance for Arctic and subarctic areas, as significant and rapid temperature changes unprecedented in the observational record are occurring. Temperatures in the Arctic are increasing at a rate of two to three times the global average temperature in the past 150 years (Wassmann et al. 2011). Along with decreasing ice cover and increasing solar irradiance, temperature increases are expected to expand the spatial and temporal windows for survival, life cycle transitions and growth of a variety of plankton species, including those responsible for toxic, or harmful, algal blooms (HABs).
Current knowledge of Arctic plankton species diversity is biased towards large species collected and observed by classical plankton nets and light microscopy. Thus, species $<20 \mu \mathrm{m}$ account for fewer than $20 \%$ of species in a more recent assessment of pan-Arctic biodiversity (Poulin et al. 2011). Recent biodiversity assessments of the area are based mainly on high throughput sequencing (Metfies et al. 2012; Elferink et al. 2017; Kilias et al. 2013, 2014; Wolf et al. 2015). While this approach reveals high diversity, especially in low size fractions (Elferink et al. 2017), high throughput sequencing still lacks species-level taxonomic resolution. However, species identification is especially necessary where closely related toxic and non-toxic species occur. Moreover, molecular diversity estimates always reveal a high degree of molecular signatures which cannot be linked to defined morphospecies (Medinger et al. 2010; Xiao et al. 2014), and this underlines the continuous and even increasing need for alpha taxonomy.

Azadinium and Amphidoma are the only genera of Amphidomataceae. They are good examples of small-sized nanoplankton described in the last decade, whose distribution and species diversity are not yet fully explored. This dinopyhcean family is of particular interest because some species produce 
azaspiracids (AZA), a group of lipophilic compounds which accumulate in shellfish (Hess et al. 2014; Twiner et al. 2014). The presence of AZA in field plankton samples and/or shellfish in Arctic and subarctic areas has not yet been reported, but that might reflect a lack of targeted studies. In any case, there is evidence for the presence of Amphidomataceae in cold northern waters. The non-toxigenic Azadinium caudatum (Halldal) Nézan \& Chomérat was described from the northern Norwegian coast in winter (Halldal 1953) and is common, and at times numerous, along the Norwegian coast (Throndsen et al. 2007). A dinophyte described as Gonyaulax parva Ramsfjell from the central Norwegian Sea towards Iceland (Ramsfjell 1959) is almost certainly a species of Azadinium (see discussion in Tillmann et al. 2014a); furthermore, other species from the Canadian Arctic (Bérard-Therriault et al. 1999; Holmes 1956), labelled as 'Goniaulax gracilis' (which was depicted and invalidly described by J. Schiller in 1935), probably refers to a species of Azadinium (see discussion in Tillmann et al. 2014a). Finally, three new, but non-toxigenic, species of Azadinium, Az. trinitatum Tillmann \& Nézan, Az. cuneatum Tillmann \& Nézan, and Az. concinnum Tillmann \& Nézan, were recently described from the North Atlantic Ocean around Iceland and the Irminger Sea (Tillmann et al. 2014a). In addition, toxigenic Amphidoma languida Tillmann, Salas \& Elbrächter (producing AZA-38 and -39) and non-toxigenic $A z$. dexteroporum Percopo \& Zingone were isolated from the area as well (Tillmann et al. 2015). Presence, diversity and distribution of Amphidomataceae on the western Greenland coast are currently unknown. A main reason for a lack of records and distribution data is that many species of Amphidomataceae are small ( $<20 \mu \mathrm{m}$ cell length) and inconspicuous, and thus often go unnoticed in routine light microscopy. Amphidomataceae are thus a good example of the necessity of applying specific molecular detection tools. A family-specific molecular PCR assay detecting all Amphidomataceae (Smith et al. 2016) and speciesspecific qPCR assays for three of the toxigenic species (Toebe et al. 2013; Wietkamp et al. 2019a) are both available. From a chemical perspective, detection of AZA using LC-MS/MS can be a complementary and sensitive analytical tool for records of toxigenic Amphidomataceae, especially when long-term Solid Phase Adsorption Toxin Tracking (SPATT) deployments allow for integration and amplification of low signal levels.

On a research survey on the $R V$ Maria $S$. Merian to the west coast of Greenland, we combined traditional onboard live microscopy with qPCR molecular detection and LC-MS/MS analysis (both discrete plankton samples and continuously deployed SPATT samplers) to specifically investigate the presence, diversity and distribution of amphidomatacean species. This baseline information evaluates the risk potential of azaspiracid shellfish poisoning (AZP) in subarctic and Arctic waters.

\section{MATERIAL \& METHODS}

\section{Hydrographic observations and sampling}

Data were collected from 25 June to 19 July 2017 onboard $R V$ Maria S. Merian (MSM65) in the central Labrador Sea and along the western coast of Greenland (Fig. 1). At each station, CTD profiles were conducted using a Seabird 'sbe911+' CTD (Sea-Bird Electronics Inc., Seattle, Washington, USA) attached to a sampling rosette. The CTD was equipped with a chlorophyll fluorescence sensor (Fluorometer, WET Labs, Philomath, Oregon, USA). Data acquisition was carried out via CTD-client on-board; post-processing was done with Seasoft V2. Temperature was corrected to ITS-90 (Preston-Thomas 1990). A total of 50 CTD stations (Fig. 1) from the central Labrador Sea and along the western coast of Greenland were sampled from specific depths using Niskin bottles. CTD Profiles are available at Pangaea (Zielinski et al. 2018). Data from surface waters (Fig. 2) represent the upper $5 \mathrm{~m}$ of each CTD cast. Graphics were generated using Ocean Data View (ODV) software (Schlitzer 2018).

Besides CTD casts at each station, surface water of the whole cruise track was investigated for temperature, salinity (model SBE45, Sea-Bird Electronics Inc., Seattle, Washington, USA) and fluorescence (model cyclops 7, Turner Design Inc., San Jose, California, USA) using a Pocket FerryBox (4H Jena, Jena, Germany). Data are available on request. The outlet of the FerryBox offers further options for sampling, e.g., for toxins.

\section{Sample processing}

Niskin bottle samples from three depths $(3 \mathrm{~m}, 10 \mathrm{~m}$, and depth of the chlorophyll maximum) were fixed with Lugol's iodine (1\% final concentration). For quantitative plankton counts, samples of these three depths were pooled, and $50 \mathrm{ml}$ and $10 \mathrm{ml}$ were settled in Utermöhl sedimentation chambers and counted with an IMR inverted microscope (Olympus, Hamburg, Germany). Counted subsample volume and magnification were adjusted for each species or protist group depending on the respective abundance. In addition, mixed water samples from three depths were used for on-board living plankton microscope observations. A 1-1 sample was pre-screened ( $20 \mu \mathrm{m}$ Nitex mesh) and gently concentrated by gravity filtration using a $5-\mu \mathrm{m}$ polycarbonate filter $(47-\mathrm{mm}$ diameter, Millipore, Eschborn, Germany). A subsample was fixed with formaldehyde ( $1 \%$ final concentration) for later SEM analysis, and the rest was examined using an inverted microscope (Axiovert 200M, Zeiss, Göttingen, Germany). Samples were screened for cells of Azadinium and Amphidoma at high magnification (x640) based on general cell size and shape, on the presence of a theca, and on the presence of a distinctly pointed apex. Cells of interest were photographed with a digital camera (Axiocam MRc5, Zeiss).

\section{DNA extraction and PCR analysis}

Plankton samples were collected at each station with Niskin bottles from $3 \mathrm{~m}, 10 \mathrm{~m}$ and from the chlorophyll maximum layer. Three litres of seawater from each depth were pre-screened through a $20-\mu \mathrm{m}$ mesh Nitex sieve, and subsequently pooled. An amount of 3-5 1 (depending on particle content) was filtered under gentle vacuum $(<200 \mathrm{mbar})$ through $5-\mu \mathrm{m}$ pore-size polycarbonate filters (47-mm diameter, Millipore). Filters were attached to the inner wall of a 50-ml plastic centrifuge tube, and repeatedly rinsed with $1 \mathrm{ml}$ pre-heated $\left(60^{\circ} \mathrm{C}\right)$ DNA lysis buffer (PL 1 buffer of the NucleoSpin Plant II kit, Macherey \& Nagel, Düren, Germany). The lysis buffer was subsequently transferred into a 5 -ml cryovial prefilled with $200-\mathrm{mg}$ glass beads (acidwashed, grain size 212-300 $\mu \mathrm{m}$, Sigma Aldrich, St. Louis, Missouri, USA) and stored at $-20{ }^{\circ} \mathrm{C}$. Not later than 1 week 


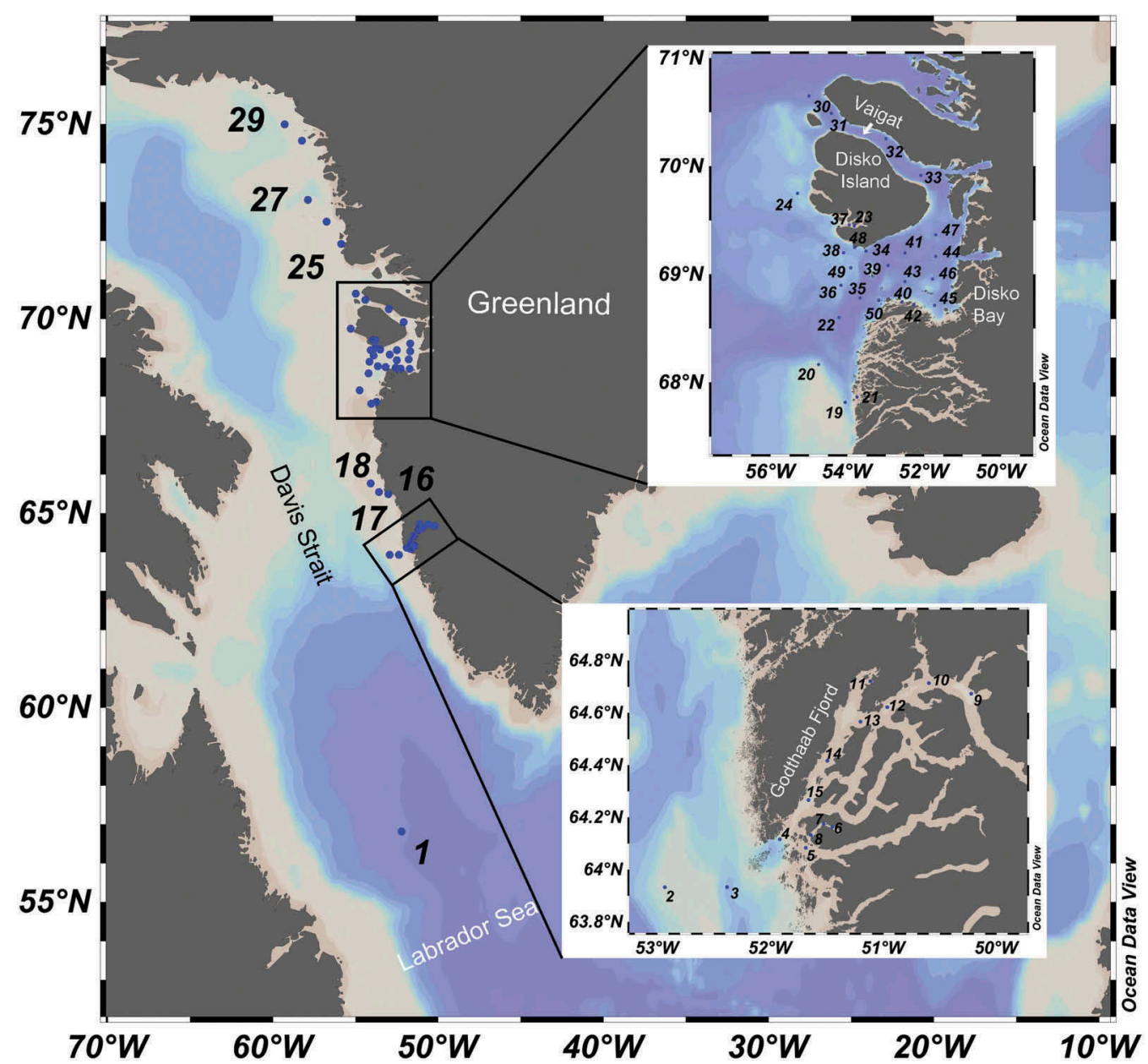

Fig. 1. Map of investigated area and location of stations of RV Maria S. Merian MSM65 cruise, 2017. Range in colours corresponds to different contour lines of water depth.

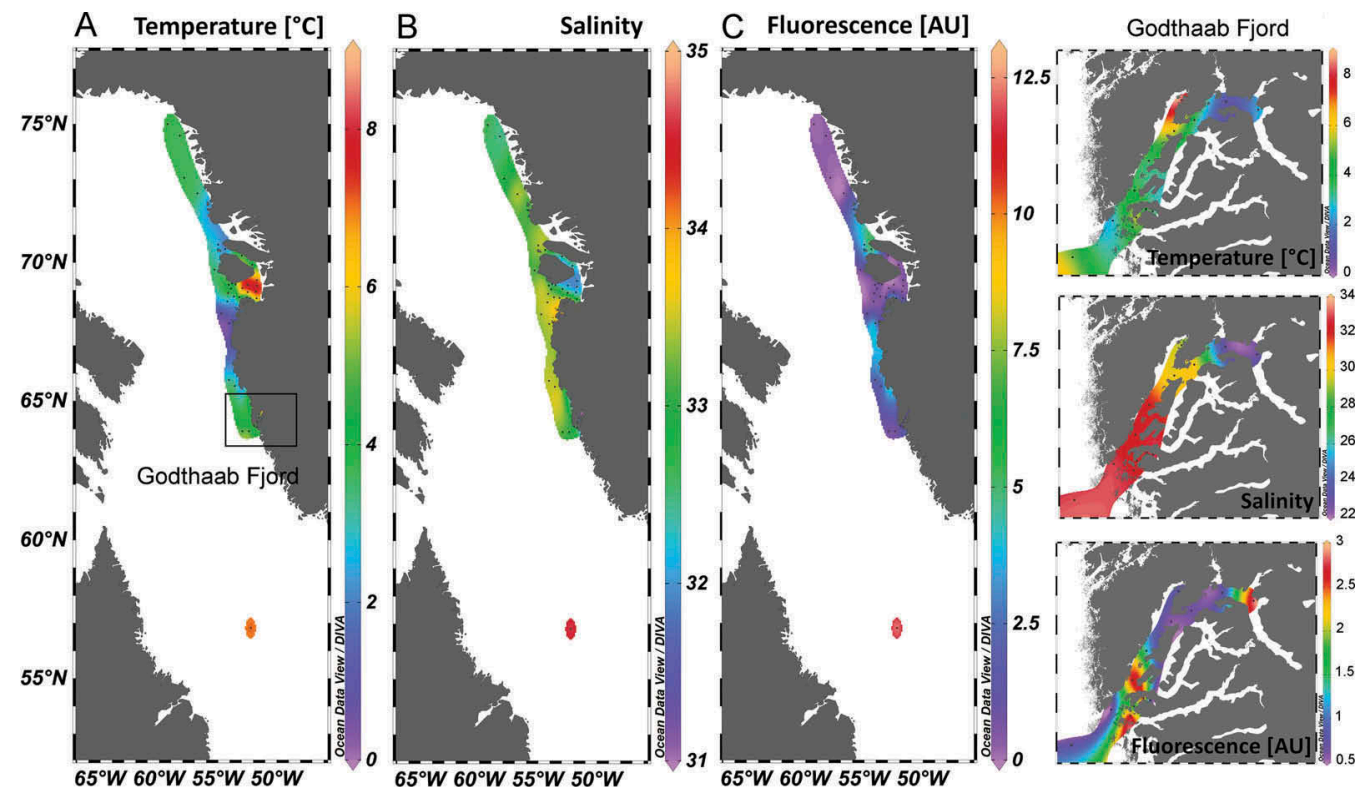

Fig. 2. Temperature (A), salinity (B) and fluorescence (C) in surface waters over the whole transect of the MSM65 campaign. The right panel shows cut-outs of the Godthaab Fjord area. 
after sampling, DNA was extracted using the NucleoSpin Plant II kit (Macherey \& Nagel) according to manufacturer's instructions.

SYBR Green PCR assays with family-specific amphidomatacean primers introduced by Smith et al. (2016) were performed on DNA extracts as a molecular pre-scanning method. One reaction contained $5 \mu$ of Fast SYBR Green Master Mix (Applied Biosystems by Thermo Fisher Scientific, Waltham, Massachusetts, USA), $3.5 \mu \mathrm{l}$ of high-grade $\mathrm{PCR} \mathrm{H}_{2} \mathrm{O}, 0.25 \mu \mathrm{l}$ of both primers (each $10 \mu \mathrm{M}$, at a final concentration of $200 \mathrm{nM}$ ) and $1 \mu \mathrm{l}$ of template DNA. Plates were analysed on a StepOne Plus realtime PCR cycler (Applied Biosystems by Thermo Fisher Scientific) following these steps: initial preheating to $95^{\circ} \mathrm{C}$ for $20 \mathrm{~s}, 40$ cycles of $3 \mathrm{~s}$ at $95^{\circ} \mathrm{C}$ and $30 \mathrm{~s}$ at $60^{\circ} \mathrm{C}$. The subsequent melt curve was performed for $15 \mathrm{~s}$ at $95^{\circ} \mathrm{C}, 60 \mathrm{~s}$ at $60^{\circ} \mathrm{C}$ and $15 \mathrm{~s}$ at $95^{\circ} \mathrm{C}$. Positive controls with known DNA concentrations as well as no-template controls (NTC) containing high-grade, nuclease-free water, were present in all PCR reactions. Primer performance and reactions were evaluated in terms of specificity and sensitivity. Melt-curve analysis was done for every reaction. Samples were analysed in triplicate, and were considered positive if at least two of the three replicates showed a fluorescence signal above the threshold before cycle 37.

Samples which showed positive results in the SYBR Green assay were tested with specific TaqMan qPCR assays on $A z$. spinosum, Az. poporum and Am. languida as described in Toebe et al. (2013) and Wietkamp et al. (2019a). Measurements were performed in triplicate. Each run contained non-template controls (NTC) and positive controls. Quantitative analyses were based on DNA standard curves as tenfold dilution series of target species' DNA $\left(10 \mathrm{ng} \mathrm{\mu l}^{-1}\right.$ to 10 fg $\mu^{-1}$ ) from cultures of $A z$. spinosum (3D9), $A z$. poporum (UTH-D4) and Am. languida (Z-LF-9-C9). For the limits of detection (LOD) and of quantification (LOQ), the definitions of Forootan et al. (2017) were applied. However, for standard curves of all three qPCR assays, the limited resolution of dilutions applied here did not allow differentiating between LOD and LOQ, which was $0.1 \mathrm{pg}^{-1}$ sample extract.

\section{Azaspiracids}

For AZA analysis of field plankton samples from discrete depths, samples were prepared and filtered as described above. Filters were placed with their back to the inner wall of a $50-\mathrm{ml}$ centrifuge tube (Sarstedt, Nümbrecht, Germany), and were repeatedly rinsed with 500-1000 $\mu \mathrm{l}$ methanol until complete decolouration of the filters. The methanolic extracts were transferred to a spinfilter (Ultrafree, $0.45-\mu \mathrm{m}$ pore-size, Millipore, Eschborn, Germany), centrifuged for $30 \mathrm{~s}$ at $800 \mathrm{x} g$, followed by transfer into autosampler vials and stored at $-20{ }^{\circ} \mathrm{C}$ until measurement.

Additional samples were taken using a FerryBox continuous sampling system. Solid Phase Adsorption Toxin Tracking (SPATT) bags $(100-\mu \mathrm{m}$ mesh, $10 \mathrm{~g}$ HP-20) were placed in a 7.5-1 plastic container that was fed by the outflow of a FerryBox system at a flow rate of $c .2$ litres $\mathrm{min}^{-1}$, which in turn was supplied by the ship seawater system. During the entire expedition, three SPATT bags were deployed: SP1: 26 June (station 2) - 04 July (station 16), Labrador Sea - Godthaab Fjord (Nuup Kargerlua); SP2: 04 July (station 16) - 11 July (station 31),
Maniitsoq transect north - Vaigat (Sullorsuaq Strait); and SP3: 11 July (station 31) - 17 July (station 50), Vaigat - Disko Bay (Qeqertarsuup tunua).

Mass spectral experiments were performed to survey a wide array of AZA with an analytical system consisting of triple quadrupole mass spectrometer (API 4000 QTrap, Sciex, Darmstadt, Germany) equipped with a TurboSpray interface coupled to LC equipment (model LC 1100, Agilent, Waldbronn, Germany) that included a solvent reservoir, inline degasser (G1379A), binary pump (G1311A), refrigerated autosampler (G1329A/G1330B), and temperature-controlled column oven (G1316A). Separation of AZA (5- $\mu$ l sample injection volume) was performed by reverse-phase chromatography on a $\mathrm{C} 8$ phase. The analytical column $(50 \times 2 \mathrm{~mm})$ was packed with $3 \mu \mathrm{m}$ Hypersil BDS $120 \AA$ (Phenomenex, Aschaffenburg, Germany) and maintained at $20^{\circ} \mathrm{C}$. The flow rate was $0.2 \mathrm{ml}$ $\mathrm{min}^{-1}$, and gradient elution was performed with two eluents, where eluent $\mathrm{A}$ was water and eluent $\mathrm{B}$ was acetonitrile/water $(95: 5 \mathrm{v} / \mathrm{v})$, both containing $2.0 \mathrm{mM}$ ammonium formate and $50 \mathrm{mM}$ formic acid. Initial conditions were 8-min column equilibration with $30 \% \mathrm{~B}$, followed by a linear gradient to $100 \% \mathrm{~B}$ in 8 min and isocratic elution until 18 min with $100 \% \mathrm{~B}$ then returning to initial conditions until $21 \mathrm{~min}$ (total run time: $29 \mathrm{~min}$ ). AZA profiles were determined in the selected reaction monitoring (SRM) mode in one period (0-18) min with curtain gas: 10 psi, CAD: medium, ion spray voltage: $5500 \mathrm{~V}$, temperature: ambient, nebuliser gas: $10 \mathrm{psi}$, auxiliary gas: off, interface heater: on, declustering potential: $100 \mathrm{~V}$, entrance potential: $10 \mathrm{~V}$, exit potential: $30 \mathrm{~V}$. SRM experiments were carried out in positiveion mode by selecting the transitions shown in Table S1.

\section{On-board isolation and culture}

On the first station in the central Labrador Sea, cells of Amphidomataceae were detected during the on-board live sample observations and were subsequently isolated using micro-capillaries into wells of 96-well plates filled with $0.2 \mathrm{ml}$ filtered seawater. Cells were subsequently re-isolated a few times using a SZH-ILLD stereomicroscope (Olympus) equipped with dark field illumination into new wells of a 96well plate. Plates were incubated at $10{ }^{\circ} \mathrm{C}$ under a photon flux density of c. $50 \mu \mathrm{mol} \mathrm{m} \mathrm{m}^{-2} \mathrm{~s}^{-1}$ in a $16: 8 \mathrm{~h}$ light:dark photoperiod in a controlled environment growth chamber (Model MIR 252, Sanyo Biomedical, Wood Dale, Illinois, USA).

\section{Characterisation of Amphidomataceae strains}

After 4 weeks of growth, primary isolation plates from the cruise were inspected in the laboratory using a SZH-ILLD stereomicroscope (Olympus) for presence of Azadinium/ Amphidoma-like cells as inferred from typical size, shape, and swimming behaviour. From each well with amphidomatacean cells, a clonal strain was established by isolation of single cells by micro-capillary. Established cultures were thus clonal but not axenic, and were routinely held in $70-\mathrm{ml}$ plastic culture flasks at $15^{\circ} \mathrm{C}$ in a natural seawater medium prepared with sterile filtered $(0.2 \mu \mathrm{m}$ VacuCap filters, Pall Life Sciences, Dreieich, Germany) Antarctic seawater (salinity, 34; $\mathrm{pH}$ adjusted to 8.0), and enriched with 1/10 strength K-medium 
(Keller et al. 1987) which was slightly modified by omitting ammonium ions.

For toxin analysis, strains were grown at $15{ }^{\circ} \mathrm{C}$ under a photon flux density of $50 \mu \mathrm{mol} \mathrm{m} \mathrm{m}^{-2} \mathrm{~s}^{-1}$ on a $16: 8 \mathrm{~h}$ light: dark photoperiod. For each harvest, cell density was determined by settling Lugol-fixed samples and counting $>800$ cells using an inverted microscope. Densely grown strains (ranging from $0.5-5 \times 10^{4}$ cells $\mathrm{ml}^{-1}$ ) were harvested by centrifugation (5810R, Eppendorf, Hamburg, Germany) of $50-\mathrm{ml}$ subsamples at $3220 \times \mathrm{g}$ for $10 \mathrm{~min}$. The cell pellet was resuspended, transferred into a microtube, centrifuged again (5415, Eppendorf, $16,000 \times \mathrm{x}, 5 \mathrm{~min}$ ), and stored frozen $\left(-20^{\circ} \mathrm{C}\right)$ until use. For selected strains, growth and harvest procedures were repeated several times to yield a high biomass and consequently lower the cell quota-based limit of detection. Numbers of cells harvested for these strains are listed in Table S2. Several cell harvests of each strain were combined in $100 \mu \mathrm{l}$ of acetone. Extraction of cell pellets was repeated four times with $100 \mu \mathrm{l}$ each and combined cell suspensions were vortexed every $10 \mathrm{~min}$ for $1 \mathrm{~h}$ at room temperature. Homogenates were centrifuged (5810 R, Eppendorf) at $15^{\circ} \mathrm{C}$ and $3220 \mathrm{x} g$ for 15 min. Filtrates were then adjusted with acetone to a final volume of $0.5 \mathrm{ml}$. The extracts were transferred to a $0.45-\mu \mathrm{m}$ pore-size spin-filter (Millipore) and centrifuged (5415R, Eppendorf) at $800 \mathrm{x} g$ for $30 \mathrm{~s}$, with the resulting filtrate being transferred into a liquid chromatography (LC) autosampler vial for LC-MS/MS analysis.

For DNA extraction, each strain was grown in $70-\mathrm{ml}$ plastic culture flasks under the standard culture conditions described above. Aliquots of $50 \mathrm{ml}$ of healthy and growing culture (based on stereomicroscopic inspection of the live culture) were harvested by centrifugation (5819R, Eppendorf, $3000 \times \mathrm{g}, 10 \mathrm{~min})$. Each pellet was transferred into a microtube, again centrifuged (5415, Eppendorf, 16,000 $\mathrm{x} g, 5 \mathrm{~min})$, and stored at $-80{ }^{\circ} \mathrm{C}$ until DNA extraction.

\section{MICROSCOPY}

Observation of living and fixed cells was carried out with a SZH-ILLD stereomicroscope (Olympus) and an Axiovert $200 \mathrm{M}$ inverted microscope (Zeiss). Observation and documentation of live cells at x1000 magnification were performed using an Axioskop 2 (Zeiss) and by recording videos using a Gryphax digital camera (Jenoptik, Jena, Germany) at full-HD resolution. Single frame micrographs were extracted using Corel VideoStudio software (Version X8 Pro). Photographs of formaldehyde-fixed cells ( $1 \%$ final concentration) were taken with an Axiocam MRc5 digital camera (Zeiss).

Cell length and width were measured at x1000 magnification using Axiovision software (Zeiss) and freshly fixed cells (formaldehyde, final concentration $1 \%$ ) of strains growing at $15{ }^{\circ} \mathrm{C}$.

For scanning electron microscopy (SEM), cells were collected by centrifugation (5810R, Eppendorf, $3220 \mathrm{x}$, $10 \mathrm{~min}$ ) of $15 \mathrm{ml}$ of culture. The supernatant was removed and the cell pellet resuspended in $60 \%$ ethanol in a $2-\mathrm{ml}$ microtube for $1 \mathrm{~h}$, at $4{ }^{\circ} \mathrm{C}$ to strip off the outer cell membrane. Subsequently, cells were pelleted by centrifugation (5415R, Eppendorf, 16,000 x $g, 5 \mathrm{~min}$ ) and resuspended in a 60:40 mixture of deionised water and seawater for $30 \mathrm{~min}$ at $4{ }^{\circ} \mathrm{C}$. After centrifugation and removal of the diluted seawater supernatant, cells were fixed with formaldehyde (2\% final concentration in a 60:40 mixture of deionised water and seawater) and stored at $4{ }^{\circ} \mathrm{C}$ for $3 \mathrm{~h}$. Cells were then collected on polycarbonate filters (Millipore, 25-mm diameter, 3- $\mu \mathrm{m}$ poresize) in a filter funnel where all subsequent washing and dehydration steps were carried out. Eight washings (2-ml MilliQdeionised water each) were followed by a dehydration series in ethanol (30\%, 50\%, 70\%, 80\%, 95\%, 100\%; 10 min each). Filters were dehydrated with hexamethyldisilazane (HMDS), first in 1:1 HMDS:EtOH, followed by twice in 100\% HMDS, and then stored under gentle vacuum in a desiccator. Finally, filters were mounted on stubs, sputter coated (SC500, Emscope, Ashford, UK) with gold-palladium and viewed with a Quanta FEG 200 scanning electron microscope (FEI, Eindhoven, Netherlands). Some SEM micrographs were presented on a black background using Adobe Photoshop 6.0 (Adobe Systems, San Jose, California, USA). Labelling of dinophyte thecal plates was done according to the Kofoidian system.

\section{Molecular phylogeny}

DNA extraction was performed using the NucleoSpin Plant II kit (Macherey \& Nagel) according to manufacturer's instructions. Sequencing reactions of the $18 \mathrm{~S} /$ small subunit (SSU), the Internal Transcribed Spacer region (ITS1, 5.8S rRNA, ITS2) and the D1/D2 region of 28S/large subunit (LSU) were performed as follows: polymerase chain reaction (PCR) was performed to amplify the aforementioned regions from the DNA extracts. Each reaction contained $16.3 \mu \mathrm{l}$ ultra-pure $\mathrm{H}_{2} \mathrm{O}, 2.0 \mu \mathrm{l}$ HotMasterTaq buffer (5Prime, Hamburg, Germany), $0.2 \mu \mathrm{l}$ dNTPs $(10 \mu \mathrm{M}), 0.2 \mu \mathrm{l}$ of each primer (10 $\mu \mathrm{M}$ ), $0.1 \mu \mathrm{l}$ of Taq Polymerase (Quantabio, Beverly, Massachusetts, USA) and $1.0 \mu$ l of extracted DNA template $\left(10 \mathrm{ng} \mu \mathrm{l}^{-1}\right)$ to a final reaction volume of $20 \mu \mathrm{l}$. PCR conditions for the amplification of the LSU and ITS were set as described in Wietkamp et al. (2019b) using the following primer sets: DirF (5'-ACC CGC TGA ATT TAA GCA TA-3') and D2CR (5'-CCT TGG TCC GTG TTT CAA GA-3') for LSU; ITSa (5'-CCA AGC TTC TAG ATC GTA ACA AGG (ACT)TC CGT AGG T-3') and ITSb (5'-CCT GCA GTC GAC A(GT)A TGC TTA A(AG)T TCA GC(AG) GG-3') for ITS. For SSU amplifications, the following settings were used: initialisation at $94{ }^{\circ} \mathrm{C}$ for $5 \mathrm{~min} ; 30$ cycles of $94^{\circ} \mathrm{C}$ for $2 \mathrm{~min}, 55^{\circ} \mathrm{C}$ for $2 \mathrm{~min}$, $68^{\circ} \mathrm{C}$ for $3 \mathrm{~min}$; a final extension at $68^{\circ} \mathrm{C}$ for $10 \mathrm{~min}$. Forward and reverse primers for SSU amplification were: $1 \mathrm{~F}\left(5^{\prime}-\mathrm{AAC}\right.$ CTG GTT GAT CCT GCC AGT - 3') and 1528R (5' - TGA TCC TTC TGC AGG TTC ACC TAC - 3').

\section{Phylogenetic analysis}

Newly obtained SSU, ITS and/or partial LSU rDNA sequences were incorporated into available Amphidoma, Azadinium and closely-related sequences in GenBank (https://www.ncbi.nlm. nih.gov/genbank/). Genbank accession numbers are listed in Table S3. Concatenated sequences were aligned using MAFFT v7.110 (Katoh \& Standley 2013) online program (http://mafft. cbrc.jp/alignment/server/). Alignments were manually checked with BioEdit v7.0.5 (Hall 1999). For Bayesian inference (BI), jModelTest (Posada 2008) was used to select the most 
appropriate model of molecular evolution using Akaike Information Criterion (AIC). Bayesian reconstruction of the data matrix was performed using MrBayes 3.2 (Ronquist \& Huelsenbeck 2003) with the best-fitting substitution model $(\mathrm{GTR}+\mathrm{G})$. Four Markov chain Monte Carlo (MCMC) chains were run for 4,000,000 generations, sampling every 100 generations. Convergence diagnostics were estimated graphically using 'are we there yet?' (http://ceb.scs.fsu.edu/awty; Nylander et al. 2008), and the first $10 \%$ of burn-in trees were discarded. A majority-rule consensus tree was created to examine posterior probabilities of each clade. Maximum-likelihood (ML) analyses were conducted with RaxML v7.2.6 (Stamatakis 2006) on the T-REX web server (Boc et al. 2012) using the model GTR $+\mathrm{G}$. Node support was assessed with 1000 bootstrap replicates.

Multiple ITS rDNA sequences of selected new strains were aligned with available Amphidoma and Azadinium sequences in GenBank using MAFFT v7.110 (Katoh \& Standley 2013) online program with default settings. Completed alignments were imported into PAUP* v4b10 (Swofford 2002) to estimate divergence rates using simple uncorrected pairwise $(\mathrm{p})$ distance matrices.

\section{Chemical analysis of azaspiracids}

Extracts of strains were screened for known AZA in the SRM mode as described above. In addition, precursor ion experiments were performed. Precursors of the characteristic AZA fragments $m / z 348, m / z 360$ and $m / z 362$ were scanned in the positive-ion mode from $\mathrm{m} / z 400$ to 900 under the following conditions: curtain gas, 10 psi; CAD, medium; ion spray voltage, $5500 \mathrm{~V}$; temperature, ambient; nebuliser gas, $10 \mathrm{psi}$; auxiliary gas, off; interface heater, on; declustering potential, $100 \mathrm{~V}$; entrance potential, $10 \mathrm{~V}$; collision energy, $70 \mathrm{~V}$; exit potential, $12 \mathrm{~V}$. Product ion spectra of the $\mathrm{m} / z$ values 830,842 and 858 were recorded in the Enhanced Product Ion (EPI) mode in the mass range from $\mathrm{m} / z 150$ to 930 . Positive ionisation and unit resolution mode were used. The following parameters were applied: curtain gas: 10 psi, CAD: medium, ion spray voltage: $5500 \mathrm{~V}$, temperature: ambient, nebulizer gas: 10 psi, auxiliary gas: off, interface heater: on, declustering potential: $100 \mathrm{~V}$, collision energy spread: $0,10 \mathrm{~V}$, collision energy: $70 \mathrm{~V}$, exit potential, $12 \mathrm{~V}$.

\section{RESULTS}

\section{Hydrography}

Surface temperature values ranged from $c .0 .6^{\circ} \mathrm{C}$ to $8.5^{\circ} \mathrm{C}$ (Fig. 2). Highest surface temperatures were found in the Labrador Sea (Station 1) and the Disco Bay area, whereas the coastline had lower temperature $\left(0.6^{\circ} \mathrm{C}\right.$ to $\left.4.5^{\circ} \mathrm{C}\right)$. Salinity values ranged from c. 22 to 35 , with the lowest salinities found in the inner fjord section of Godthaab Fjord (c. 22) and Disco Bay, close to Jacobshaven (Illusiat; c. 31; Fig. 2). High fluorescence signals were identified in the Labrador Sea (c. $12 \mathrm{AU}$ ), at the entrance of the Vaigat area (4-5 AU), and within outer and inner section of the Godthaab Fjord (c. 3 AU; Fig. 2).

\section{General plankton composition}

Phytoplankton composition and abundance determined from net tows and quantitative Uthermöhl counts revealed a high diversity of microplankton and locally quite different communities. This reflected late spring bloom dominance by diatoms, and/or high biomass of colonial flagellates such as Phaeocystis pouchetii (Hariot) Lagerheim and/or Dinobryon balticum (Schütt) Lemmermann, or post-bloom communities dominated by low densities of various dinoflagellate species. The first station in the open Labrador Sea revealed a high biomass of micro- and nanoplankton with noticeably high abundance of a small species of Prorocentrum and of an unknown haptophyte species. Along the Greenland coast and inside Godthaab Fjord and Disko Bay, plankton communities had high abundance of different species of flagellates and diatoms. Among the latter, there was a conspicuous bloom of Chaetoceros debilis Cleve in certain parts of the Godthaab Fjord, and locally high abundance of Thalassiosira spp. or Chaetoceros socialis H.S. Lauder in other parts of the study area. The most important and abundant flagellate species were two colony-forming species: the haptophyte Phaeocystis pouchetii and the chrysophyte Dinobryon balticum. Dinoflagellate communities consisted mainly of a highly diverse community of heterotrophic species (e.g., Gyrodinium spp., Protoperidinium spp., Amphidinium spp.) or undetermined species of unknown trophic status, whereas photosynthetic dinoflagellates (e.g., Protoceratium reticulatum (Claparéde \& Lachmann) Bütschli, Dinophysis spp., Alexandrium spp., Margalefidinium sp., Heterocapsa spp.) were generally of low abundance and biomass.

\section{On-board microscopy records of Amphidomataceae}

On-board microscopy using live samples revealed the presence of Amphidomataceae at the first station in the central Labrador Sea (Figs 3-11). Identification was based on size, shape, and the presence of a distinctly pointed apex. No attempt was made to identify cells to species. Quantitative plankton counts using the sedimentation technique and Lugol-fixed samples revealed abundant, small, thecate dinoflagellates classified as

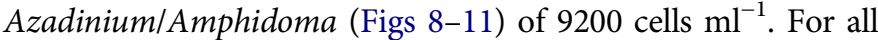
other stations inspected along the Greenland coast, no microscopic records of Amphidomataceae were noted with certainty.

\section{PCR assays}

Of the 50 stations sampled, 33 were positive with the SYBR Green amphidomatacean PCR assay (Fig. 12). In Godhaab Fjord, negative hits were restricted to a few inner stations. Whereas most of the transit stations off the coast (stations 16-21, 25-27) were negative, Amphidomataceae were present at the two northernmost stations, and at all but four stations in the Disko Bay area. Positive hits of the species-specific qPCR assays were much more restricted. Considering the DNA extraction volume and the filtered water volume, the limit of detection of $0.1 \mathrm{pg}$ target DNA $\mu^{-1}$ corresponded here to $c$. $0.4-0.6$ cells $1^{-1}$. 


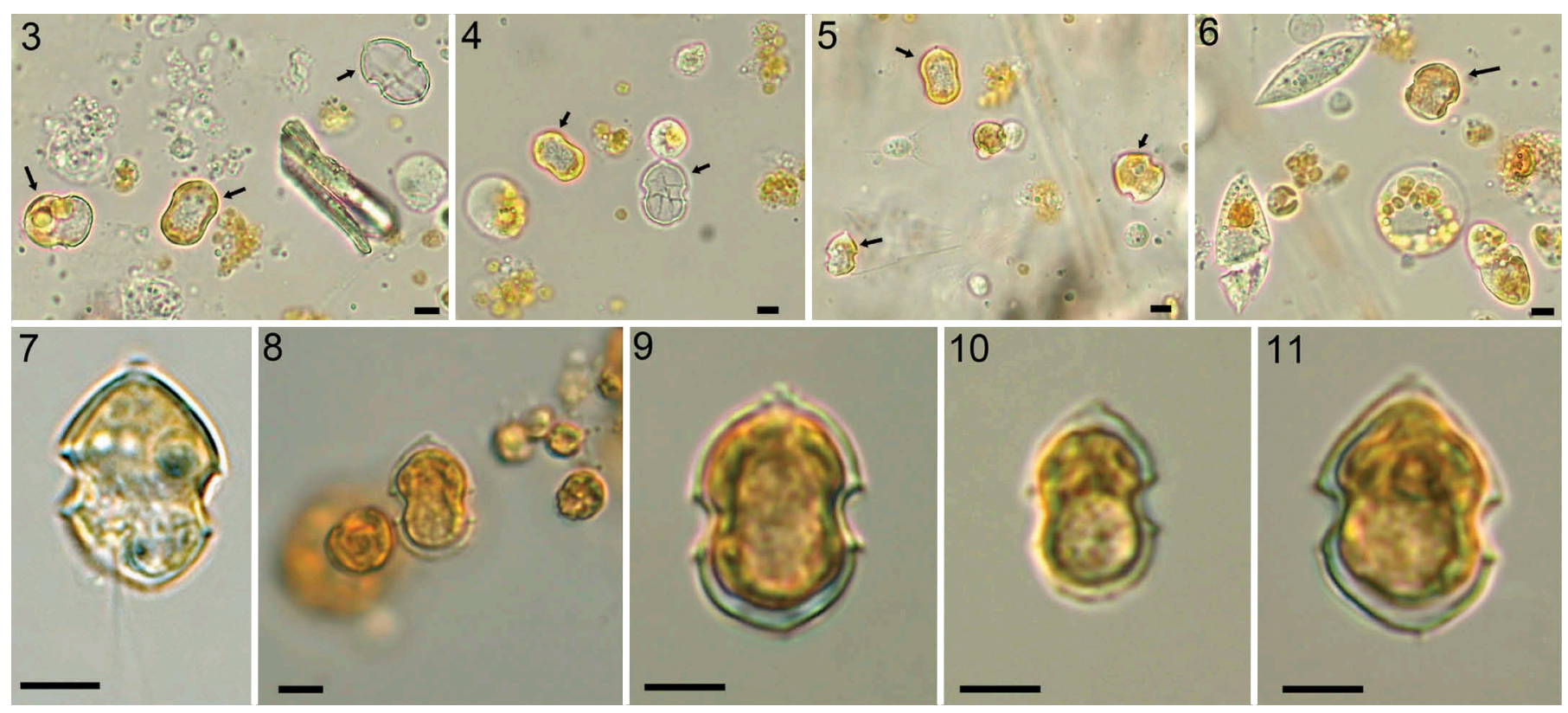

Figs 3-11. Records of Amphidomataceae from the central Labrador Sea (station 1).

Figs 3-7. Living samples with amphidomatacean cells or empty thecae (both designated by arrows). Scale bars $=5 \mu \mathrm{m}$.

Figs 8-11. Amphidomatacean cells in Lugol-fixed Utermöhl samples. Scale bars $=5 \mu \mathrm{m}$.

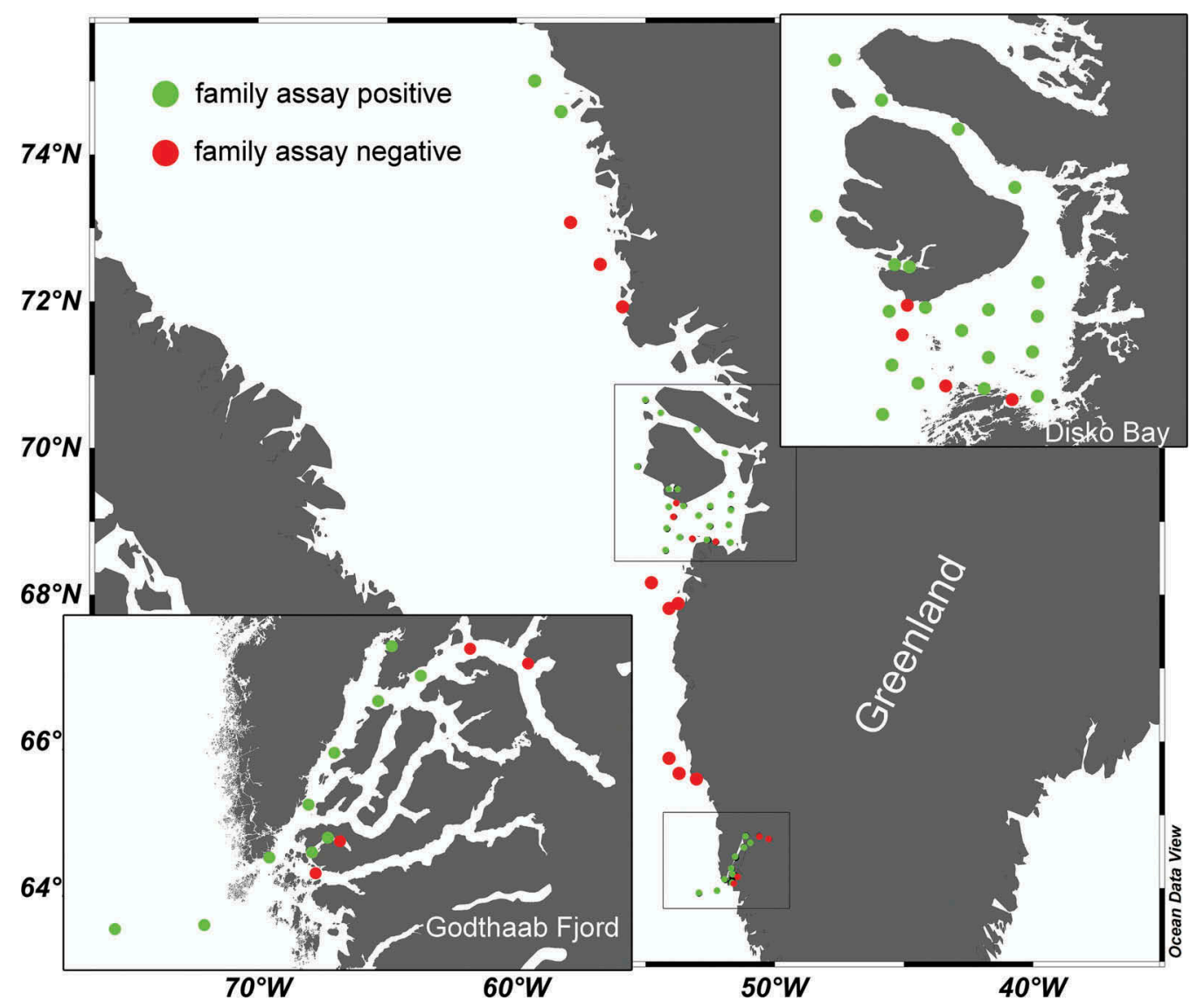

Fig. 12. Map showing PCR presence (green) or absence (red) of positive signals using Amphidomataceae family primers.

All samples were negative for $A z$. spinosum Elbrächter \& Tillmann. Amphidoma languida was detected only at the first station in the central Labrador Sea with 117 cells $\mathrm{l}^{-1}$. Positive records with background abundance $\left(1-2\right.$ cells $\left.1^{-1}\right)$ for $A z$. poporum Tillmann \& Elbrächter occurred at stations 14 and 22 only. 


\section{AZA in field samples}

None of the known AZA listed in Table S1 was detected in the 5-20 $\mu \mathrm{m}$ size fractions of seawater samples. The limits of detection (signal-to-noise ratio $=3$ ) of these measurements ranged between 7 and $12 \mathrm{pg} \mathrm{l}^{-1}$ seawater depending on water volume filtered and filter extraction volume. In addition to plankton samples, solid phase adsorption toxin tracking (SPATT) bags were continuously employed in a FerryBox sampling surface water throughout the expedition, but did not contain AZA above the LOD of $6 \mathrm{pg} \mathrm{g}^{-1}$ resin.

\section{Azadinium, new strains}

On-board single-cell isolation yielded 18 clonal amphidomatacean strains. All strains displayed a similar and conspicuous swimming behaviour consisting of a slow movement interrupted by short 'jumps' in various directions. Identification of all strains was based on morphology as examined by LM and SEM and was confirmed for all strains by rRNA sequence comparison (Table 1). The newly available strains comprised four species including $A z$. obesum Tillmann \& Elbrächter (12 strains), Az. trinitatum (two strains), Az. dexteroporum (one strain), and three strains of a new species.

\section{Azadinium perforatum Tillmann, Wietkamp \& H.Gu sp. nov.} Figs 13-41

DESCRIPTION: Small photosynthetic thecate Dinophyceae; cells 14.6 to $20.0 \mu \mathrm{m}$ long and 9.9 to $14.4 \mu \mathrm{m}$ wide; cingulum broad (c. $20 \%$ of cell length) and postmedian; epitheca conical and ending in a small but distinctly pointed apical pore; hypotheca hemispherical with a very broad and long sulcus and with a single, very small antapical spine; tabulation formula: Po, cp, X, 6', 0a, 6", 6C, 5S, 6"', 2"'; thecal pores present on the pore plate; a ventral pore located on the right ventral side in a notch of the pore plate.

HOLOTYPE: SEM stub prepared from clonal strain AZA-2H (designated CEDiT2019H103), deposited at the Senckenberg Research Institute and Natural History Museum, Centre of Excellence for Dinophyte Taxonomy (Wilhelmshaven, Germany).

ISOTYPES: Formalin-fixed sample prepared from clonal strain AZA-2H (designated CEDiT2019I104) deposited at the Senckenberg Research Institute and Natural History Museum, Centre of Excellence for Dinophyte Taxonomy (Wilhelmshaven, Germany)

TYPE LOCALITY: Central Labrador Sea $\left(56^{\circ} 49.42^{\prime} \mathrm{N} ; 52^{\circ} 13.15^{\prime} \mathrm{W}\right)$.

HABITAT: Marine plankton.

STRAIN ESTABLISHMENT: Sampled and isolated by U. Tillmann on 28 June 2017.

ETYMOLOGY: The epithet (Latin perforatus - pierced, penetrated) is inspired by the presence of small pores on the pore plate.

\section{Morphology}

Using light and electron microscopy, all three clonal strains identified as $A z$. perforatum sp. nov. (AZA-2C, AZA-2E, AZA-2H) were identical in terms of morphology and plate pattern. The selected strain AZA-2H is described in detail.

Cells of $A z$. perforatum sp. nov. were ovoid and slightly dorsoventrally compressed (Figs 13-22). Cells of strain AZA-
Table 1. Strain information. All strains were analysed by light microscopy and scanning electron microscopy. For none of the strains were azaspiracids detected. For all strains, LSU and ITS sequence data were obtained, and for all three $A z$. perforatum strains there are also SSU sequences (see Supplementary Table S3).

\begin{tabular}{|c|c|c|c|c|c|}
\hline & & Length $(\mu \mathrm{m})$ & Width $(\mu \mathrm{m})$ & I/w ratio & \\
\hline Species & Strain & $\begin{array}{l}\text { Mean } \pm s \\
\text { Min-max }\end{array}$ & $\begin{array}{l}\text { Mean } \pm s \\
\text { Min-max }\end{array}$ & Mean $\pm s$ & $\mathrm{n}$ \\
\hline Az. obesum & AZA-1B & $\begin{array}{c}15.3 \pm 1.0 \\
13.1-17.0\end{array}$ & $\begin{array}{c}11.6 \pm 1.0 \\
9.2-13.8\end{array}$ & $1.33 \pm 0.05$ & 53 \\
\hline Az. obesum & $A Z A-1 C$ & $\begin{array}{c}14.8 \pm 0.8 \\
13.2-16.4\end{array}$ & $\begin{array}{c}10.8 \pm 0.8 \\
9.3-12.7\end{array}$ & $1.37 \pm 0.06$ & 53 \\
\hline Az. obesum & AZA-1F & $\begin{array}{c}15.8 \pm 0.9 \\
13.3-18.0\end{array}$ & $\begin{array}{c}12.0 \pm 0.8 \\
10.2-14.1\end{array}$ & $1.32 \pm 0.05$ & 51 \\
\hline Az. obesum & $A Z A-1 G$ & $\begin{array}{c}14.9 \pm 0.9 \\
12.4-16.7\end{array}$ & $\begin{array}{c}11.0 \pm 0.7 \\
9.7-12.4\end{array}$ & $1.36 \pm 0.06$ & 50 \\
\hline Az. obesum & AZA-2B2 & $\begin{array}{c}14.5 \pm 0.9 \\
12.9-16.4\end{array}$ & $\begin{array}{c}10.7 \pm 0.8 \\
9.2-12.8\end{array}$ & $1.36 \pm 0.06$ & 54 \\
\hline Az. obesum & AZA-2D & $\begin{array}{c}15.2 \pm 0.8 \\
14.0-17.3\end{array}$ & $\begin{array}{c}11.4 \pm 0.9 \\
9.7-13.9\end{array}$ & $1.34 \pm 0.06$ & 53 \\
\hline Az. obesum & $A Z A-2 G$ & $\begin{array}{c}\mathbf{1 5 . 6} \pm 0.8 \\
13.7-17.1\end{array}$ & $\begin{array}{c}11.9 \pm 0.8 \\
10.6-13.8\end{array}$ & $1.31 \pm 0.05$ & 54 \\
\hline Az. obesum & AZA-ZE4 & $\begin{array}{c}16.1 \pm 1.0 \\
14.1-17.7\end{array}$ & $\begin{array}{c}12.2 \pm 1.1 \\
10.0-14.3\end{array}$ & $1.32 \pm 0.06$ & 53 \\
\hline Az. obesum & AZA-ZE7 & $\begin{array}{c}16.6 \pm 2.3 \\
12.4-22.2\end{array}$ & $\begin{array}{c}13.3 \pm 2.6 \\
8.8-20.0\end{array}$ & $1.26 \pm 0.08$ & 82 \\
\hline Az. obesum & AZA-ZE8 & $\begin{array}{c}\mathbf{1 5 . 3} \pm 0.9 \\
13.8-17.5\end{array}$ & $\begin{array}{c}11.1 \pm 0.9 \\
9.7-13.4\end{array}$ & $1.37 \pm 0.06$ & 53 \\
\hline Az. obesum & AZA-ZE9 & $\begin{array}{c}15.3 \pm 1.3 \\
13.2-17.3\end{array}$ & $\begin{array}{c}11.0 \pm 0.8 \\
9.5-12.8\end{array}$ & $1.40 \pm 0.06$ & 52 \\
\hline Az. obesum & AZA-ZE11 & $\begin{array}{c}\mathbf{1 5 . 5} \pm 0.9 \\
13.6-17.3\end{array}$ & $\begin{array}{c}\mathbf{1 1 . 8} \pm 0.8 \\
10.3-13.6\end{array}$ & $1.32 \pm 0.06$ & 52 \\
\hline Az. trinitatum & $A Z A-2 F$ & $\begin{array}{c}13.7 \pm 0.8 \\
12.1-15.4\end{array}$ & $\begin{array}{c}9.2 \pm 0.7 \\
7.6-11.3\end{array}$ & $1.50 \pm 0.08$ & 44 \\
\hline Az. trinitatum & AZA-ZE10 & $\begin{array}{c}13.5 \pm 0.8 \\
12.0-15.9\end{array}$ & $\begin{array}{c}9.3 \pm 0.6 \\
8.1-10.8\end{array}$ & $1.46 \pm 0.07$ & 50 \\
\hline Az. dexteroporum & AZA-2B1 & $\begin{array}{c}10.5 \pm 0.7 \\
9.1-13.2\end{array}$ & $\begin{array}{c}7.5 \pm 0.6 \\
6.5-10.0\end{array}$ & $1.40 \pm 0.06$ & 57 \\
\hline Az. perforatum & $A Z A-2 C$ & $\begin{array}{c}17.6 \pm 1.1 \\
14.6-19.2\end{array}$ & $\begin{array}{c}12.0 \pm 0.8 \\
9.9-13.5\end{array}$ & $1.47 \pm 0.05$ & 59 \\
\hline Az. perforatum & AZA-2E & $\begin{array}{c}\mathbf{1 7 . 8} \pm 1.1 \\
15.5-19.5\end{array}$ & $\begin{array}{c}12.3 \pm 0.9 \\
10.4-14.0\end{array}$ & $1.45 \pm 0.06$ & 56 \\
\hline Az. perforatum & AZA-2H & $\begin{array}{c}18.0 \pm 0.9 \\
15.3-20.0\end{array}$ & $\begin{array}{c}12.6 \pm 0.9 \\
9.9-14.4\end{array}$ & $1.49 \pm 0.07$ & 84 \\
\hline
\end{tabular}

$2 \mathrm{H}$ had a mean length of $18.0 \mu \mathrm{m}(15.3$ to $20.0 \mu \mathrm{m}, \mathrm{n}=84)$ and a mean width of $12.6 \mu \mathrm{m}$ (9.9 to $14.4 \mu \mathrm{m}, \mathrm{n}=84$ ), resulting in a mean length:width ratio of about 1.5 (Table 1). The domeshaped episome terminated in a distinctly acuminated apical pore (Figs 13, 17, 18). The episome was slightly longer than the hemispherical hyposome. The broad cingulum was thus slightly postmedian in position, descending but only slightly displaced (Figs 15, 16).

A single large, lobed and reticulate chloroplast expanded through the entire cell (Figs 13-18,21) and no indication of a pyrenoid was visible using LM. The large, ellipsoid nucleus was positioned in cell centre (Figs 13, 20, 22). Cytokinesis occurred in motile cells and was of the desmoschisis type in which the parental theca was shared between the two sister cells (Fig. 19).

Thecal plates were thin, but could be clearly observed in light microscopy (Figs 13-20), and were stainable with calcofluor white (not shown). However, because of the delicateness of the plates, the Kofoidian pattern was better resolved by SEM (Figs 23-37, all prepared from the holotype SEM stub). 

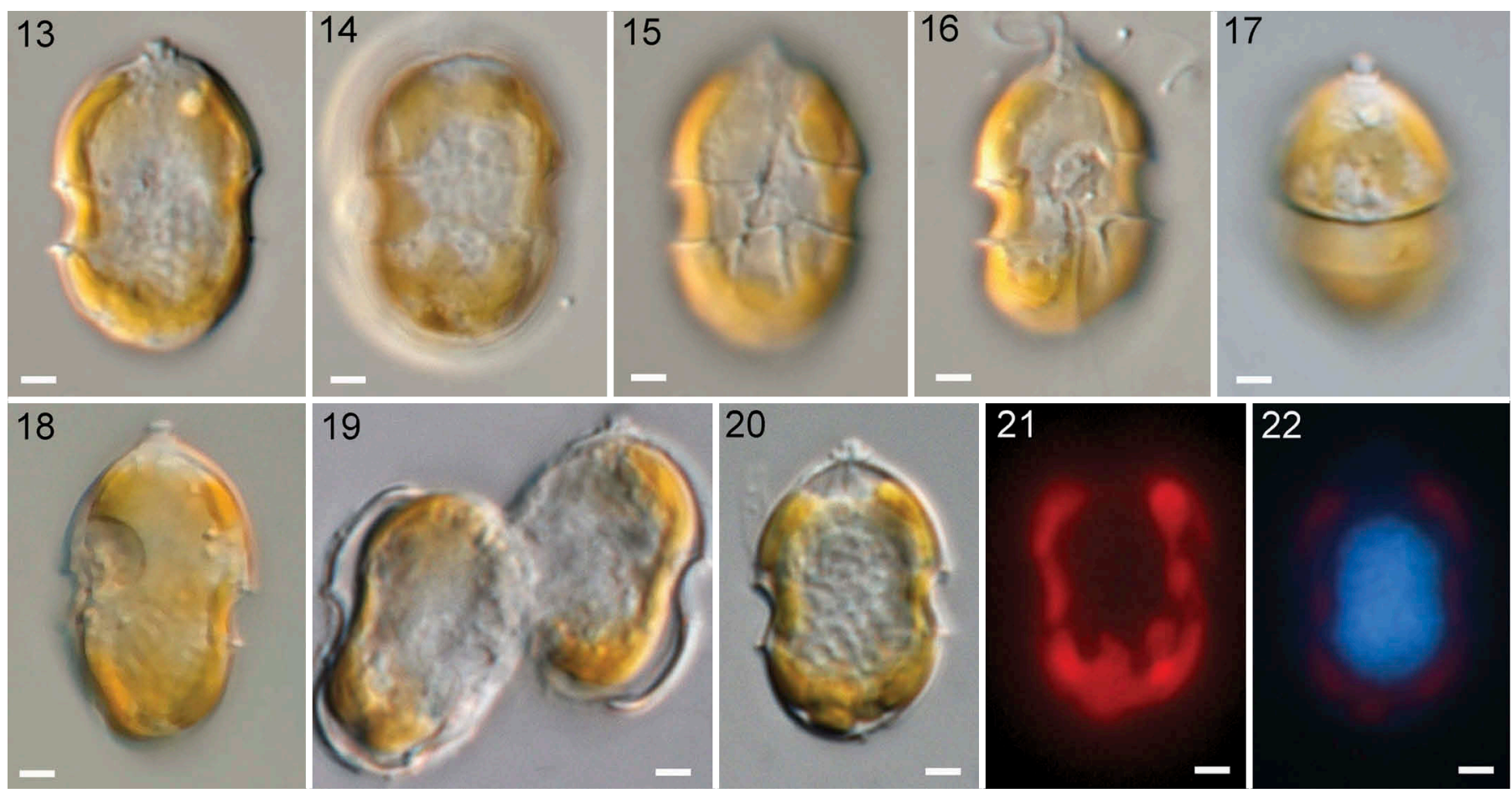

Figs 13-22. Azadinium perforatum sp. nov. (strain AZA-2H): LM of living (Figs 13-18) and formaldehyde-fixed (Figs 19-22) cells.

Figs 13-18. Living cells showing general size and shape. Scale bars $=2 \mu \mathrm{m}$.

Fig. 19. Formalin fixed cell, late stage of cell division (desmoschisis). Scale bar $=2 \mu \mathrm{m}$.

Figs 20-22. Same cell stained with DAPI in brightfield (Fig. 20), with blue light excitation (Fig. 21) to show chloroplast shape and location, or with UV excitation (Fig. 22) to indicate nuclear shape and location. Scale bars $=2 \mu \mathrm{m}$.

The plate formula was Po, cp, X, 4', 3a, 6", 6C, 5S, 6"', 2"', and is schematically drawn in Figs $38-41$. Plates were generally smooth, but growth bands of thecal plates were occasionally faintly visible as striated rows running parallel to plate sutures (e.g., Figs 24-27). The presence of these growth bands was restricted to certain sutures.

The acuminate epitheca terminated in the prominent apical pore complex (APC; Figs 23-28) which was composed of three plates: a pore plate (Po) covered by a cover plate (cp), and the canal plate X (Figs 29-31). The pore plate was teardrop-shaped and confined by a collar formed by edges of the apical plates. The collar was narrow and raised, and thus was distinct in LM (Fig. 20). On the tapered ventral side of the pore plate, the collar was open. In the centre of the apical pore plate (Po), a teardrop-shaped pore emerged which was covered by a cover plate (cp). A small X-plate was located where the pore plate abutted the first apical plate. Internal views to determine the exact shape of the X-plate were not obtained. From the exterior, the X-plate had a characteristic threedimensional structure with finger-like protrusions contacting the apical cover plate (Figs 30,31). In addition to the APC, the epitheca was composed of 13 thecal plates forming rows of four apical, three anterior intercalary, and six precingular plates (Fig. 29). The six-sided first apical plate was elongated rhomboid or diamond-shaped with a narrow posterior part (Fig. 32). The other three apical plates were small and sixsided, with the dorsal plate $3^{\prime}$ being smaller than lateral plates $2^{\prime}$ and $4^{\prime}$ (Fig. 29). The sutures of plate $3^{\prime}$ to its neighbouring apical plates were very short so that the epithecal intercalary plates almost contacted the pore plate. Three small anterior intercalary plates were symmetrically arranged on the dorsal side of the epitheca (Figs 27, 28, 29, 33) with the middle intercalary plate $2 \mathrm{a}$ slightly smaller than the others. All three intercalary plates were five-sided and in contact with two precingular plates. All six precingular plates were of almost equal size, taller than wide, and arranged symmetrically with the suture between plate $3 "$ and $4 "$ in mid-dorsal position. Both ventrally-located precingular plates (1" and 6") were four-sided, and all other precingulars were five-sided.

The hypotheca was composed of six postcingular and two antapical plates (Fig. 35). Of the six postcingular plates, the two ventrally-located plates were slightly narrower than the other postcingular plates. All postcingular plates were rather long with the lateral and dorsal postcingular plates longer than the two ventral postcingular plates (Figs 23-25). Both antapical plates extended on the dorsal side towards the sulcus. They were different in size with the larger plate 2 '"' bearing a minute antapical spine located almost in the middle of the cell close to the suture between plates 1 "' and 2"' (Figs 23, 24, 35).

The cingulum was wide, about one-fifth of total cell length, and was only slightly displaced by about one-third of its width (Figs 23, 24). There were six cingular plates (Fig. 36). Five of the cingular plates were of comparable size, but the right cingular plate C6 was distinctly narrower and invaded the sulcal area on its left side with an irregularly shaped wing-like extension (arrows in Figs 23, 24, 26). The central sulcal area was deeply concave and the sulcus extended with a slightly concave plate (Sp) along most of the hypotheca. The small central sulcal plates were difficult to resolve because of the internal vaulted structure of the flagellar pore region. Nevertheless, five sulcal plates were 

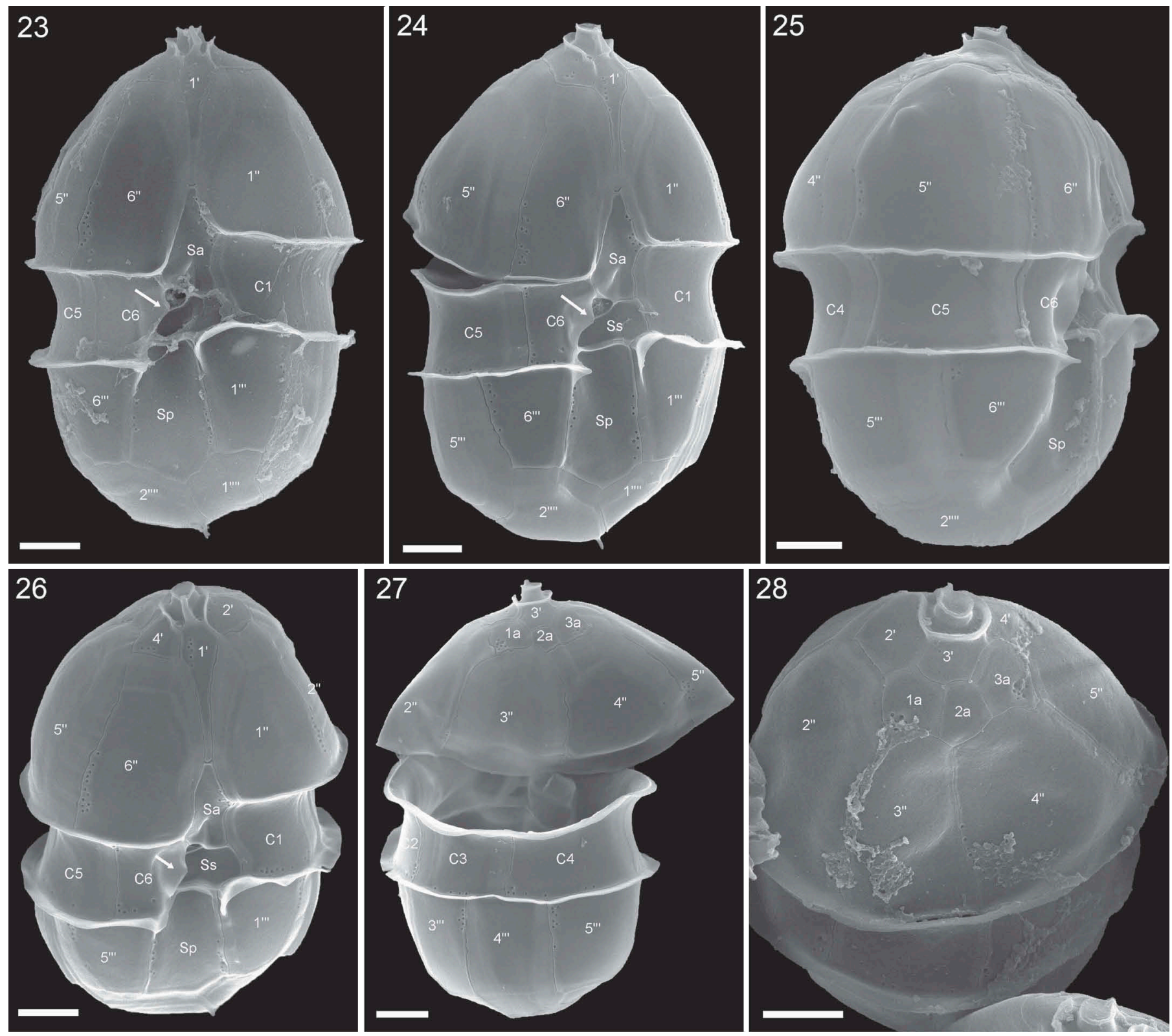

Figs 23-28. SEM of Azadinium perforatum sp. nov. (strain AZA-2H).

Fig. 23. Theca in ventral view. Scale bar $=2 \mu \mathrm{m}$.

Figs 24, 25. Thecae in right lateral view. Scale bar $=2 \mu \mathrm{m}$.

Fig. 26. Theca in apical right lateral view. Scale bar $=2 \mu \mathrm{m}$.

Fig. 27. Theca in dorsal view. Scale bar $=2 \mu \mathrm{m}$.

Fig. 28. Theca in apical dorsal view. Scale bar $=2 \mu \mathrm{m}$.

identified (Figs 36, 37). The large anterior sulcal plate (Sa) was asymmetrical pentagonal and partly intruded the epitheca with a triangular, tapered anterior part (Figs 23, 24,. 26). Two small plates, namely a median sulcal $(\mathrm{Sm})$ and a right sulcal $(\mathrm{Sd})$ plate formed the inverted part of the sulcus (Figs 36, 37). A broad left sulcal plate (Ss) ran horizontally from C1 to C6, thereby separating the posterior sulcal plate (Sp) from the other sulcal plates. The large posterior sulcal plate was approximately twice as long as wide, and triangular at its posterior end (Figs 23-26).

Thecal plates had a limited number of thecal pores of diameter about $0.1 \mu \mathrm{m}$. On precingular, cingular, and postcingular plates the pores were arranged mainly as rows parallel to some plate sutures (Figs 23-28). The first apical plate had a characteristic anterior row of five to ten pores (Figs 29, 30,32), whereas pores on other apical and intercalary plates were scattered and ranged from zero to eight pores per plate (Figs 29, 33). The median intercalary plate 2a was usually free of pores, but occasionally one pore occurred (Figs 29, 33). Dorsal plates $3 "$ and $4 "$ of the pre- and postcingular series were free of pores. A few small pores were present on the second antapical plate, whereas the first antapical plate had no pores (Fig. 35). Some pores were consistently present on all three larger sulcal plates, i.e., on Sa, Ss and Sp (Figs 23, 24, 26). 

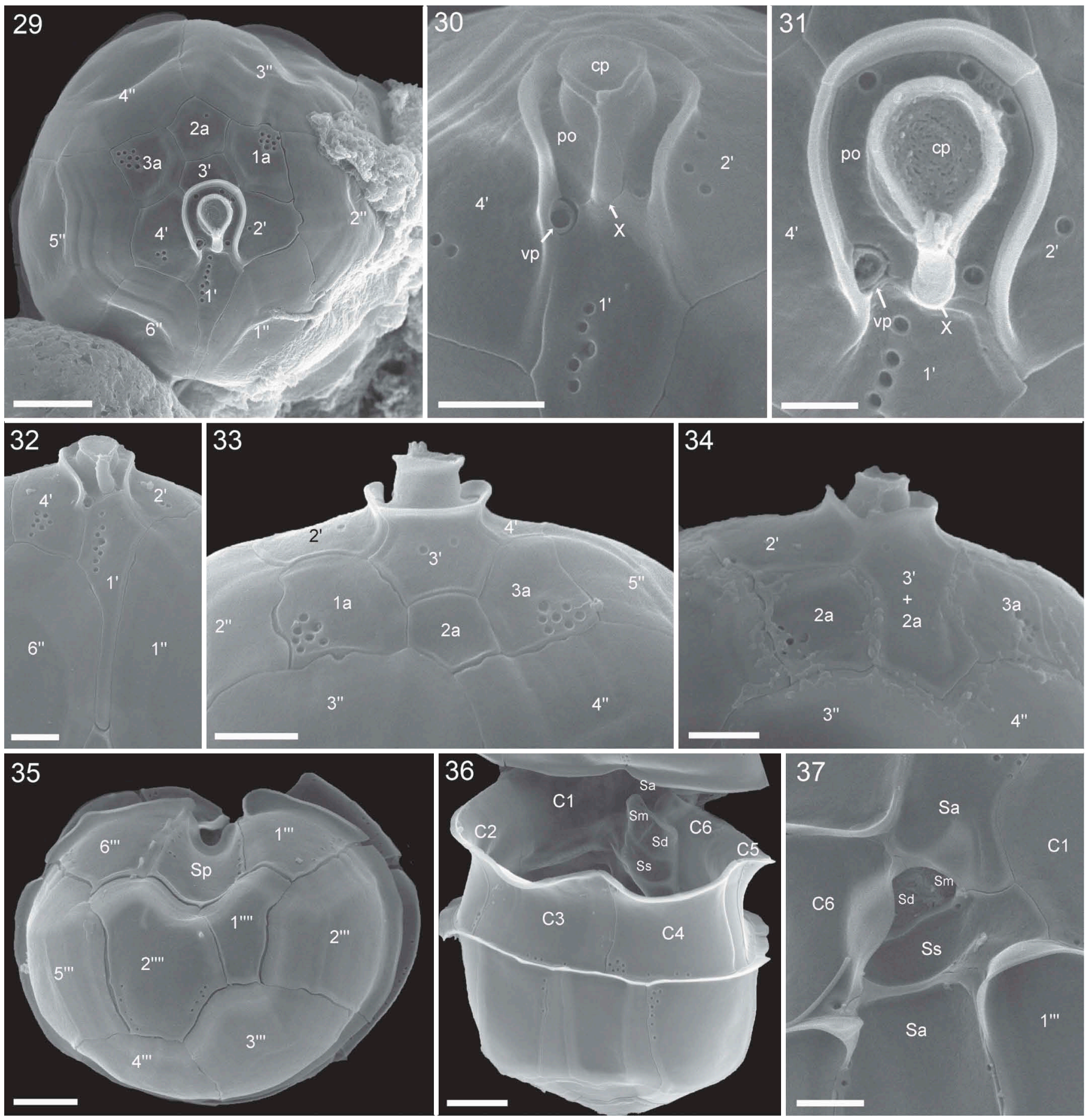

Figs 29-37. Azadinium perforatum sp. nov. (strain AZA-2H): SEM micrographs of different cells to illustrate epithecal plate arrangement.

Fig. 29. Apical view. Scale bar $=2 \mu \mathrm{m}$.

Fig. 30. Detailed view of apical pore complex in central view. Scale bar $=1 \mu \mathrm{m}$.

Fig. 31. Detailed view of apical pore complex in apical view. Scale bar $=0.5 \mu \mathrm{m}$.

Fig. 32. Ventral view of first apical plate. Scale bar $=1 \mu \mathrm{m}$.

Figs 33,34 . Detailed dorsal view of apical and anterior intercalary plates. Note Fig. 34 suggests that plate $3^{\prime}$ and $2 \mathrm{a}$ are fused. Scale bars $=1 \mu \mathrm{m}$.

Fig. 35. Antapical view of hypothecal plates. Scale bar $=2 \mu \mathrm{m}$.

Fig. 36. Dorsal/apical view of hypotheca showing series of cingular plates with interior view of sulcal plates. Scale bar $=2 \mu \mathrm{m}$.

Fig. 37. Details of sulcal plate arrangement in external view. Scale bar $=1 \mu \mathrm{m}$.

The plate pattern shown in Figs 38-41 was standard; however, some variation occurred in culture. A common (but not quantified) variation was the lack of a suture between plates $3^{\prime}$ and $2 \mathrm{a}$, leading to a single elongated dorsal apical plate extending posteriorly between, and separating the two remaining anterior intercalary plates (Fig. 34). 
38

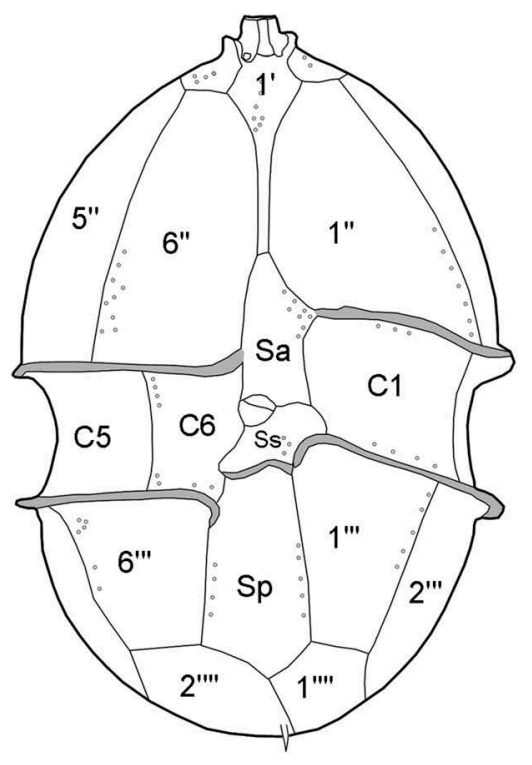

40

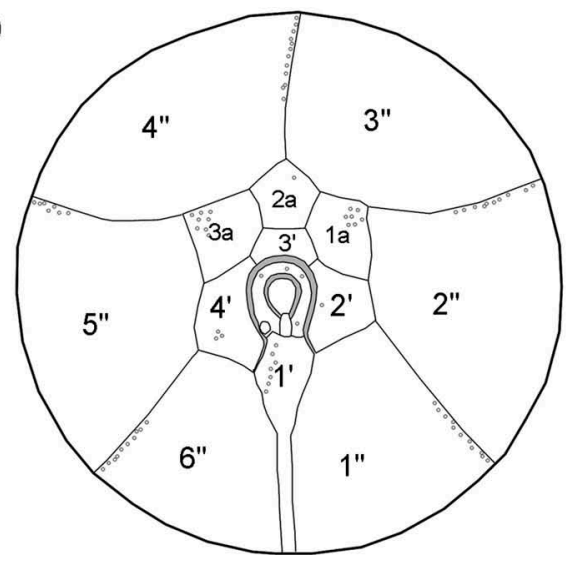

39
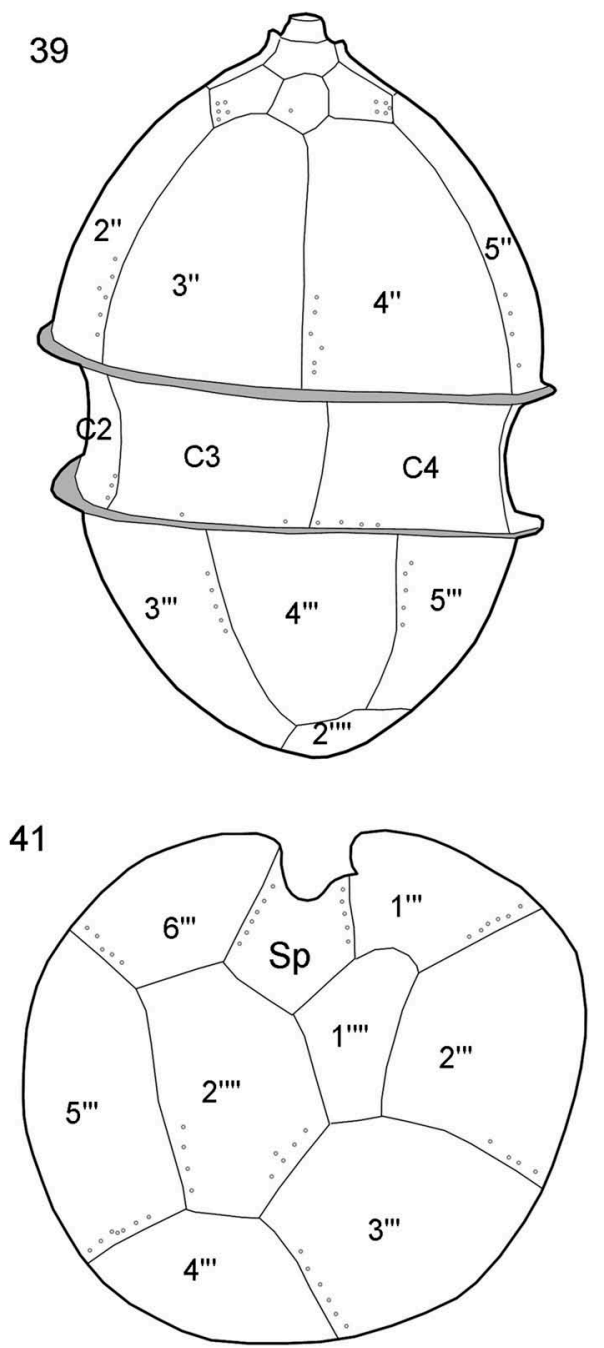

Figs 38-41. Azadinium perforatum sp. nov. Schematic illustrations of tabulation. Plate labels according to Kofoidian system. Positions of thecal pores indicated in Figs 38-41 as small grey circles; position of small antapical spine indicated in Fig. 38.

Fig. 38. Ventral view.

Fig. 39. Dorsal view.

Fig. 40. Apical view.

Fig. 41. Antapical view.

\section{Morphology of other strains}

\section{Azadinium obesum Tillmann \& Elbrächter}

Figs $42-52$

With 12 new strains, Azadinium obesum (Figs 42-52) was the species most often obtained from single-cell isolation at station 1. All strains of $A z$. obesum shared identical morphology in LM and SEM. No pyrenoid was visible using light microscopy (Figs 42-44). SEM revealed the Kofoidian plate pattern, Po, cp, X, 4', $3 a, 6 ", 6 \mathrm{C}, 5 \mathrm{~S}, 6 " ', 2$ "', and plate size and arrangement as described for the type species (Figs 46-52). As a distinctive morphological feature, the ventral pore was located on the left margin of plate 1' (Figs 46, 50). For all strains of $A z$. obesum, plate $2 \mathrm{a}$ was present in both quadra- (i.e. in contact with one precingular plate) and penta-configuration (in contact with two precingular plates; Figs 49, 50). Epithecal intercalary plates were relatively small, and the first (1a) was not in contact with plate 1" (Figs 49, 50).

\section{Azadinium dexteroporum Percopo \& Zingone}

Figs 53-62

One strain was identified as Azadinium dexteroporum (Figs 53-62). Cells of strain AZA-2B1 were distinctly smaller than other strains (Table 1). In LM, the very broad and excavated cingulum, acuminate apex, distinct antapical spine, and relatively small pyrenoid visible by its starch cup, were observed (Figs 53-55). Dividing cells retained their motility throughout mitosis and cytokinesis, the latter being of the desmoschisis type, i.e., parental theca shared by the two sister cells (Fig. 56).

The Kofoidian plate pattern and most plate details (Figs 57-62) conformed to the species description. The distinctly smaller central intercalary plate $2 \mathrm{a}$ was quadrangular 


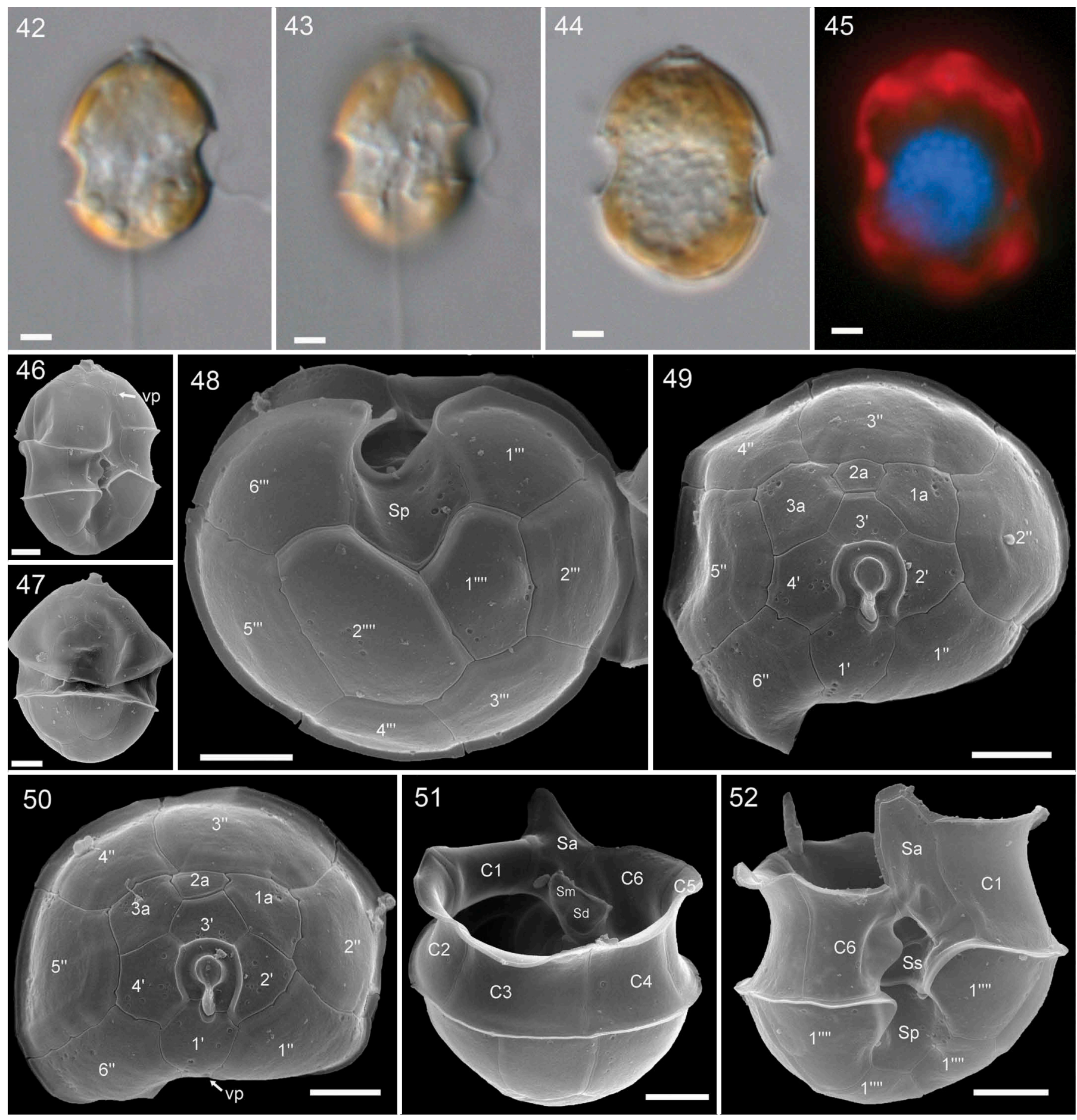

Figs 42-52. Light and scanning electron micrographs of Azadinium obesum (strain AZA-2D). vp, ventral pore.

Figs 42, 43. $L M$, living cells in ventral view. Scale bars $=2 \mu \mathrm{m}$.

Figs 44, 45. Formalin fixed cells in brightfield (Fig. 44) or with calcofluor staining and epifluorescense (UV excitation; Fig. 45) to illustrate shape and location of nucleus (blue) and chloroplast (red). Scale bars $=2 \mu \mathrm{m}$.

Fig. 46. SEM of theca in ventral view. Scale bar $=2 \mu \mathrm{m}$.

Fig. 47. SEM of theca in dorsal view. Scale bar $=2 \mu \mathrm{m}$.

Fig. 48. Hypothecal plates in antapical view. Scale bar $=2 \mu \mathrm{m}$.

Figs 49, 50. Epithecal plates in apical view. Note plate 2a in quadra (Fig. 49) or penta (Fig. 50) configuration. Scale bars $=2 \mu \mathrm{m}$.

Fig. 51. Dorsal/apical view of hypotheca showing series of cingular plates with an interior view of sulcal plates. Scale bar $=2 \mu \mathrm{m}$.

Fig. 52. Hypotheca in ventral view showing details of sulcal plates. Scale bar $=2 \mu \mathrm{m}$.

and often almost symmetrically located above plate 3" (Figs 58 , 60). However, a penta-configuration (i.e., plate $2 \mathrm{a}$ was pentagonal) was also present, with plate 2 a contacting plates 3" and 4" (Figs 58, 59). Different from the Mediterranean type strain, plate 2a of the Labrador Sea strain (AZA-2B1) was not concave, although at times the thick plate overgrowth of adjoining plates gave a slightly sunken appearance to this plate (Fig. 58). As the most characteristic feature, the ventral 

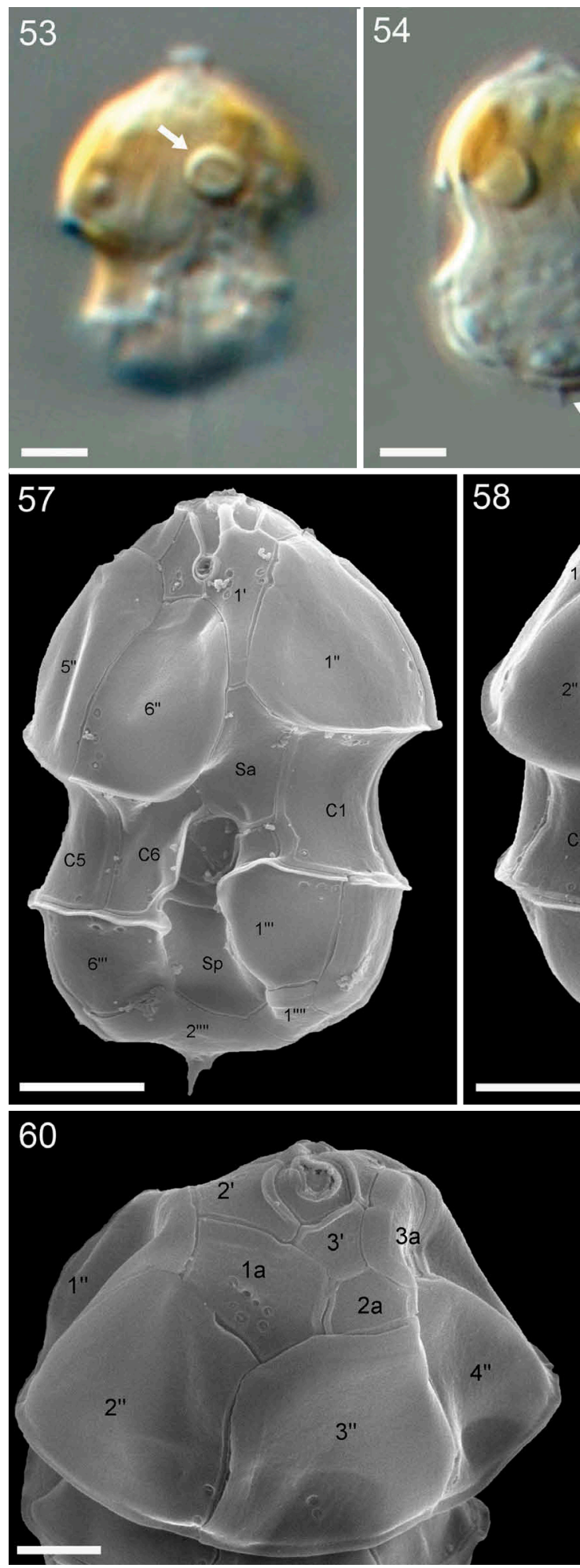
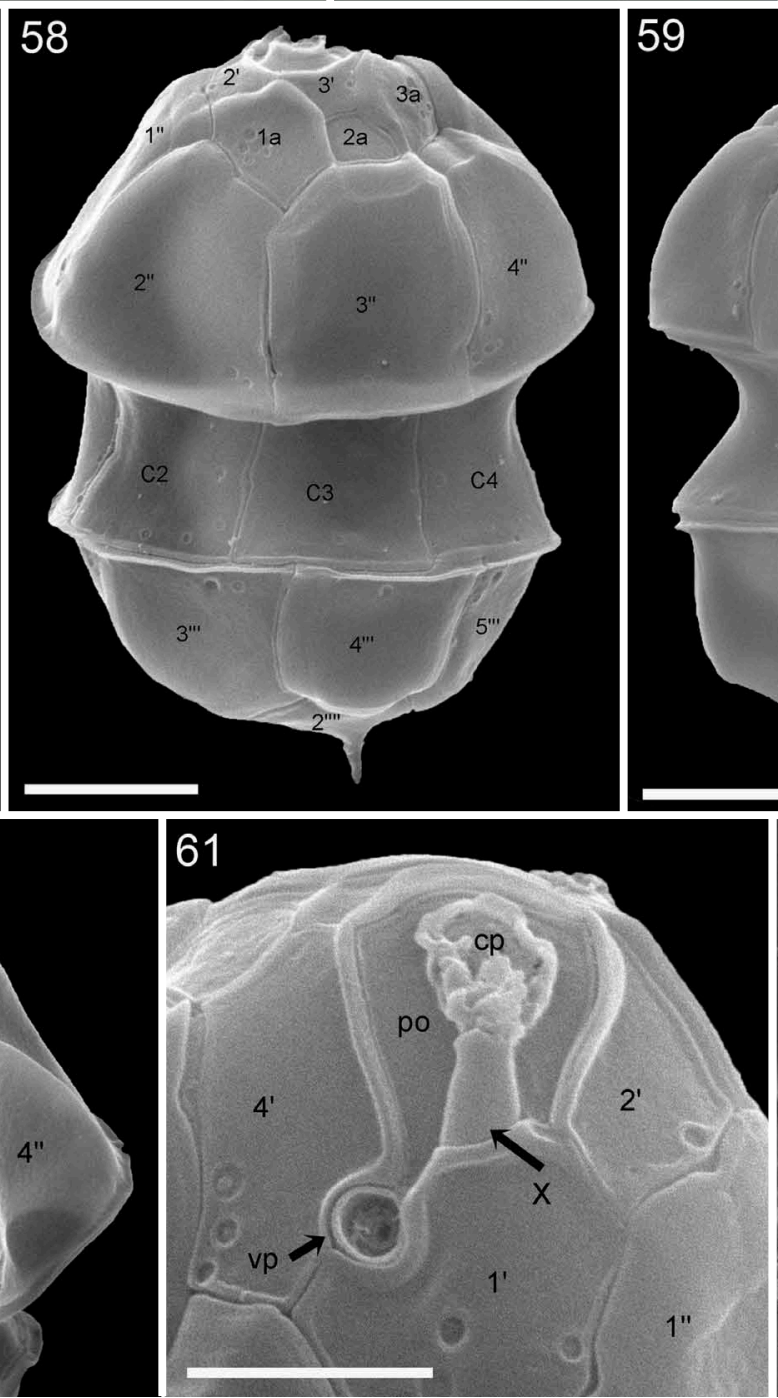
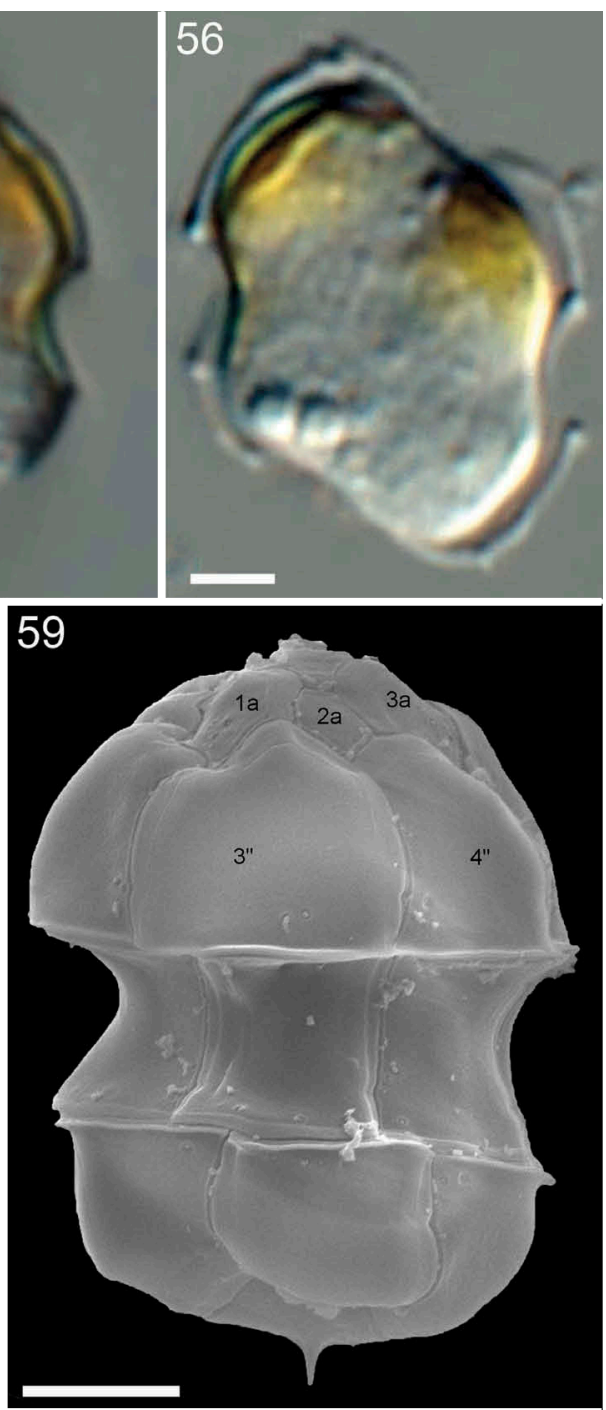

62

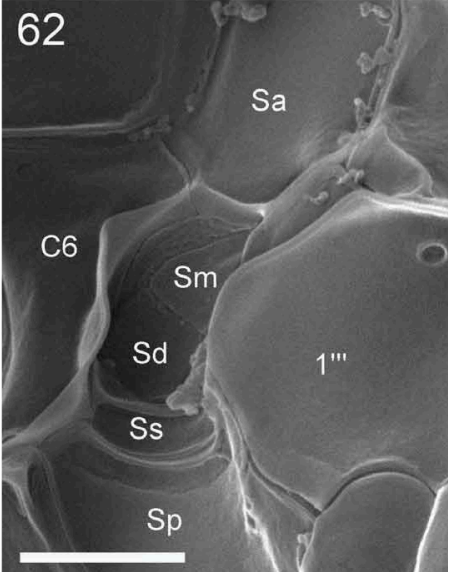

Figs 53-62. Light and scanning electron micrographs of Azadinium dexteroporum (strain AZA-2B1). cp, cover plate; $X, X$-plate; vp, ventral pore; po, pore plate.

Figs 53-56. LM, living cells showing general size and shape, one pyrenoid (arrow in Fig. 53) in episome, and presence of an antapical spine (arrow in Fig. 54). Scale bars $=2 \mu \mathrm{m}$.

Fig. 56. Dividing cell in late stage of desmoschisis. Scale bar $=2 \mu \mathrm{m}$.

Fig. 57. SEM of theca in ventral view. Scale bar $=2 \mu \mathrm{m}$.

Figs 58, 59. SEM of thecae in or dorsal view. Note plate 2a in quadra (Fig, 58) or penta (Fig. 59) configuration. Scale bars $=2 \mu \mathrm{m}$.

Fig. 60. Detailed dorsal view of apical area showing a plain plate 2a. Scale bar $=1 \mu \mathrm{m}$.

Fig. 61. Detailed view of apical pore complex showing position of ventral pore. Scale bar $=1 \mu \mathrm{m}$.

Fig. 62. Details of sulcal plate arrangement in external view. Scale bar $=1 \mu \mathrm{m}$. 
pore (vp) was located at the distal end of the somewhat elongated right side of the asymmetric pore plate (Fig. 61). As has been observed in the central sulcal region of the type strain, occasionally an additional structure was visible above Sm and Sd (Fig. 62). However, it could not be verified if this represented an additional sulcal platelet, or an internal outgrowth of plate C6 extending to both central sulcal plates.

\section{Azadinium trinitatum Tillmann \& Nézan}

Figs $63-72$

Two strains of Azadinium trinitatum (AZA-2F, AZA-ZE10) were obtained. Cells varied in shape with an epitheca ranging from conical to more dome-shaped. Viewed by LM (Figs 63-65), one pyrenoid was located in the episome. SEM examination
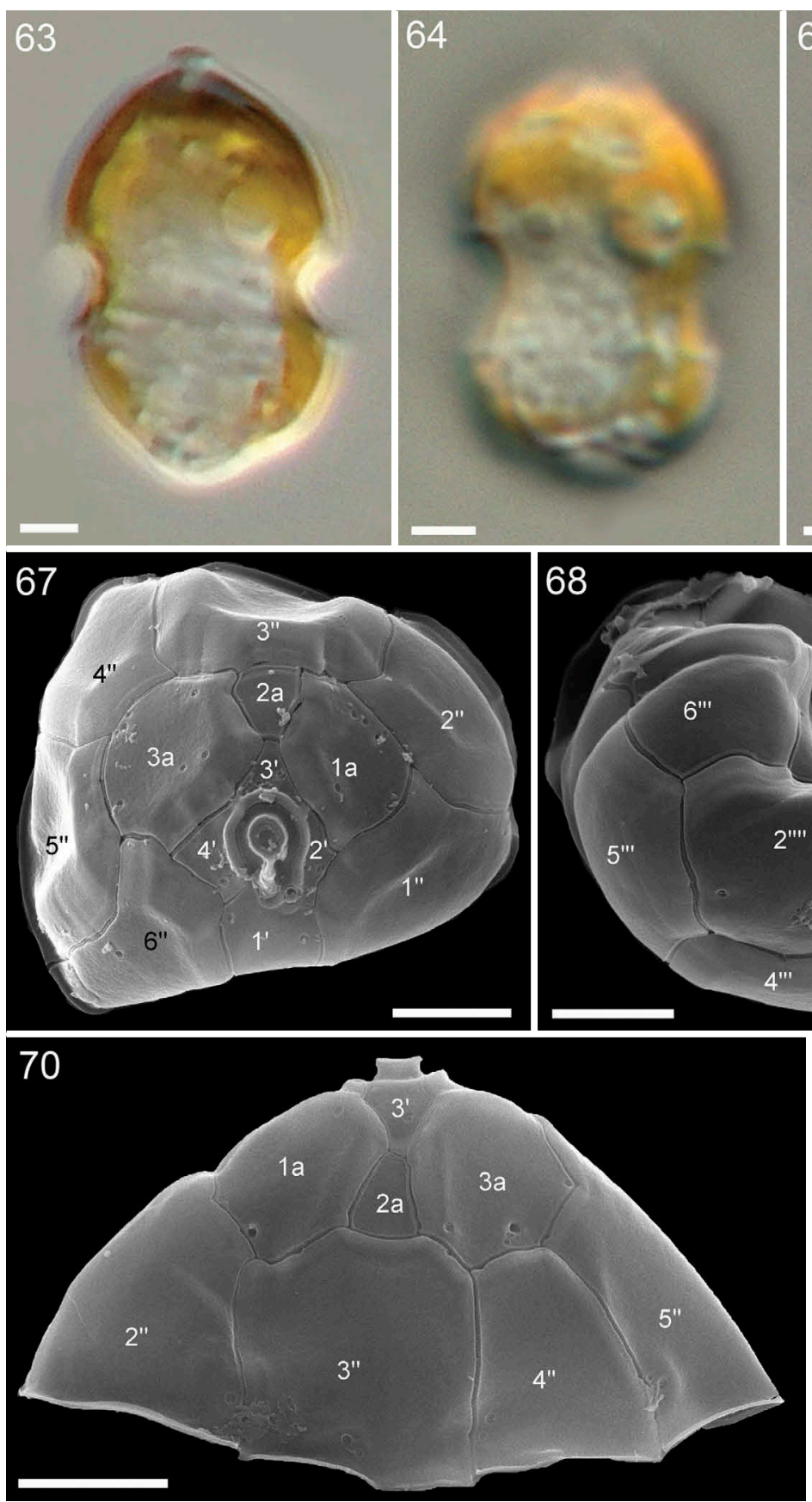
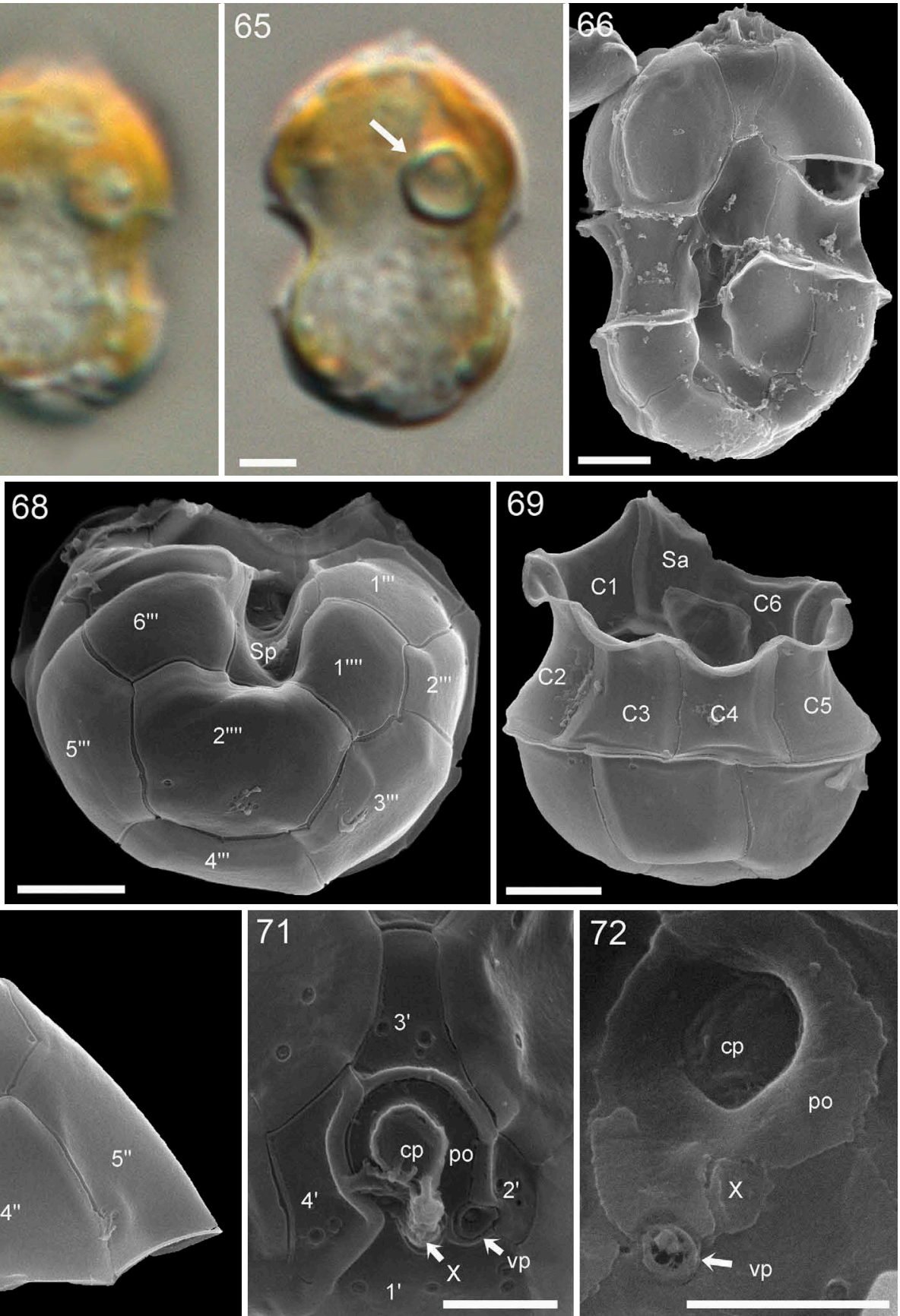

Figs 63-72. Light and scanning electron micrographs of Azadinium trinitatum (strain AZA-2F). cp, cover plate; X, X-plate; vp, ventral pore; po, pore plate.

Figs 63-65. LM, living cells showing general size and shape, and one pyrenoid (arrow in Fig. 65) in episome. Scale bars $=2 \mu \mathrm{m}$.

Fig. 66. SEM of theca in ventral view. Scale bar $=2 \mu \mathrm{m}$.

Fig. 67. Epithecal plates in apical view. Scale bar $=2 \mu \mathrm{m}$.

Fig. 68. Hypothecal plates in antapical view. Scale bar $=2 \mu \mathrm{m}$.

Fig. 69. Dorsal view of hypotheca showing series of cingular plates with an interior view of sulcal plates. Scale bar $=2 \mu \mathrm{m}$.

Fig. 70. Epitheca in dorsal view. Scale bar $=2 \mu \mathrm{m}$.

Fig. 71. Detailed view of apical pore complex in external view. Scale bar $=1 \mu \mathrm{m}$.

Fig. 72. Detailed view of apical pore complex in internal view. Scale bar $=1 \mu \mathrm{m}$. 
(Figs 66-72) showed most morphological details described for the type strain, i.e., presence of relatively small apical plates, a broad contact of plates $1 \mathrm{a}$ and 1 ", and a ventral pore located at the left lateral side of the pore plate in a cavity of the 1 ' plate at the tip of an elongated side of a slightly asymmetric pore plate. However, different from the type strain from Iceland, both cultured strains from the Labrador Sea lacked any indication of an antapical spine on plate 2 "'.

\section{AZA analysis strains}

All strains tested were negative for AZA. The limits of detection (LOD) in the SRM mode for the targeted analysis of known AZA ranged between 0.7 and $23 \mathrm{ag}$ cell $^{-1}$, depending on analysed biomass. LOD in the less sensitive precursor ion mode for the search of unknown AZA variants ranged between 29 and 596 ag cell $^{-1}$ (Table S2).

\section{Sequence data and phylogeny}

Three strains of $A z$. perforatum (AZA-2C, $-2 \mathrm{E},-2 \mathrm{H}$ ) shared identical SSU rDNA sequences.

For LSU rDNA sequence comparison, $A z$. dexteroporum strain AZA-2B1 shared identical sequences with strain 1-D12 and differed from the type strain at nine positions $(92.54 \%$ similarity for $624 \mathrm{bp}$ ). The AZA-ZE10 strain of Az. trinitatum differed from AZA-2F at three positions (99.60\% similarity, out of $742 \mathrm{bp}$ ) and differed from N-39-04 at five positions (99.33\% similarity, for $742 \mathrm{bp}$ ). Various strains of $A z$. obesum (AZA-1B, -1F, -2B2, -2D, -2G, -ZE8, -ZE9) and the type strain $2 \mathrm{E} 10$ shared identical sequences, and strains AZA-1C, $-1 G$, -ZE7 shared identical sequences, too. They differed from each other at three positions (99.59\% similarity, for $730 \mathrm{bp}$ ). Az. perforatum strains AZA-2C and $-2 \mathrm{H}$ shared identical sequences and differed from AZA-2E at only one position (99.84\% similarity, for $619 \mathrm{bp}$ ).

For ITS rDNA sequence comparison, Az. dexteroporum strain AZA-2B1 differed from strain 1-D12 at one position ( $99.81 \%$ similarity, for $529 \mathrm{bp}$ ) and from the type strain at 23 positions (95.60\% similarity, for $529 \mathrm{bp}$ ). Strain $A z$. trinitatum (AZA-ZE10) differed from AZA-2F at three positions $(99.45 \%$ similarity, for $544 \mathrm{bp}$ ) and differed from N-39-04 at four positions (99.26\% similarity, for $544 \mathrm{bp}$ ). Various strains of Az. obesum (AZA-1F, -2D, -2G, -ZE4, -ZE8, -ZE9) and the type strain $2 \mathrm{E} 10$ had identical sequences as did strains AZA$1 \mathrm{C},-1 \mathrm{G}$. They differed at three positions $(99.46 \%$ similarity, for $560 \mathrm{bp})$. Az. perforatum strain AZA-2H differed from AZA-2C and $-2 \mathrm{E}$ at three and four positions $(99.51 \%$ and $99.35 \%$ similarity, for $616 \mathrm{bp}$ ). Uncorrected pairwise genetic distances for selected Azadinium and Amphidoma strains and species based on ITS rDNA sequences ranged from 0.002 to 0.319 (Table 2).

Maximum likelihood (ML) and Bayesian inference (BI) analysis based on combined SSU, ITS and partial LSU rDNA sequences yielded similar phylogenetic trees. The BI tree is illustrated in Fig. 73. The family Amphidomataceae was well resolved with moderate support (0.75 BPP/100 BS). The new species $A z$. perforatum was monophyletic with maximal support (1.0 BPP/100 BS) and was a sister clade to Amphidoma parvula and Am. languida with strong support (0.97 BPP/100 BS). The group diverged earlier than other species of Amphidomataceae, followed by Azadinium concinnum, with moderate support $(0.7 \mathrm{BPP} / 100 \mathrm{BS})$. All other Azadinium species grouped with moderate support $(0.82$ $\mathrm{BPP} / 100 \mathrm{BS})$. Azadinium dexteroporum strain AZA-2B1 grouped with strain 1-D12 with maximal support, which was a sister clade to the type strain from Italy. Both new $A z$. triniatatum strains (AZA-ZE10 and $-2 \mathrm{~F}$ ) grouped with maximal support, and made a sister clade of strains from Norway and Iceland, with maximal support. All Az. obesum strains grouped with maximal support. The group consisted of two clades formed by strains from the North Atlantic Ocean with strong support $(0.94 \mathrm{BPP} / 100 \mathrm{BS}$ and $0.99 \mathrm{BPP} / 100 \mathrm{BS}$, respectively), and a third clade was formed by a strain from northeast Pacific Ocean.

\section{Azadinium spp. in the Labrador Sea field sample Figs 74-109}

SEM analysis of the concentrated formaldehyde-fixed bottle sample of station 1 in the central Labrador Sea confirmed the presence of species for which culture strains were obtained, i.e. Az. perforatum, Az. dexteroporum, Az. obesum and Az. trinitatum. Cells of $A z$. obesum in the field sample were most easily

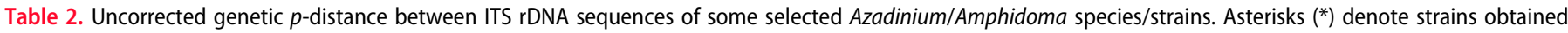
in this study.

\begin{tabular}{|c|c|c|c|c|c|c|c|c|c|c|}
\hline & $\begin{array}{c}A z . \\
\text { dexteroporum } \\
\text { AZA-2B1* }\end{array}$ & $\begin{array}{c}A z . \\
\text { dexteroporum } \\
\text { (type) }\end{array}$ & $\begin{array}{c}\text { Az. } \\
\text { obesum } \\
\text { AZA-1G* }\end{array}$ & $\begin{array}{c}\text { Az. } \\
\text { obesum } \\
\text { 2E10 }\end{array}$ & $\begin{array}{c}\text { Az. } \\
\text { trinitatum } \\
\text { AZA-2F* }\end{array}$ & $\begin{array}{c}A z . \\
\text { trinitatum } \\
4 \mathrm{~B} 11\end{array}$ & $\begin{array}{c}A z . \\
\text { concinnum } \\
1 C 6\end{array}$ & $\begin{array}{c}\text { Az. } \\
\text { perforatum } \\
\text { AZA-2H* }\end{array}$ & $\begin{array}{c}\text { Am. } \\
\text { languida } \\
\text { SM1 }\end{array}$ & $\begin{array}{c}\text { Am. } \\
\text { parvula } \\
\text { H-1E9 }\end{array}$ \\
\hline Az. dexteroporum AZA-2B1* & - & & & & & & & & & \\
\hline Az. dexteroporum (type) & 0.038 & - & & & & & & & & \\
\hline Az. obesum AZA-1G* & 0.143 & 0.146 & - & & & & & & & \\
\hline Az. obesum 2E10 & 0.142 & 0.144 & 0.002 & - & & & & & & \\
\hline Az. trinitatum AZA- $2 \mathrm{~F}^{*}$ & 0.151 & 0.156 & 0.055 & 0.053 & - & & & & & \\
\hline Az. trinitatum 4B11 & 0.150 & 0.154 & 0.047 & 0.046 & 0.006 & - & & & & \\
\hline Az. concinnum $1 \mathrm{C} 6$ & 0.276 & 0.261 & 0.251 & 0.253 & 0.250 & 0.250 & - & & & \\
\hline Az. perforatum AZA- $2 \mathrm{H}^{*}$ & 0.270 & 0.277 & 0.258 & 0.258 & 0.277 & 0.272 & 0.293 & - & & \\
\hline Am. languida SM1 & 0.295 & 0.286 & 0.290 & 0.292 & 0.294 & 0.293 & 0.277 & 0.325 & - & \\
\hline Am. parvula $\mathrm{H}-1 \mathrm{E} 9$ & 0.312 & 0.302 & 0.307 & 0.309 & 0.319 & 0.317 & 0.285 & 0.295 & 0.206 & - \\
\hline
\end{tabular}




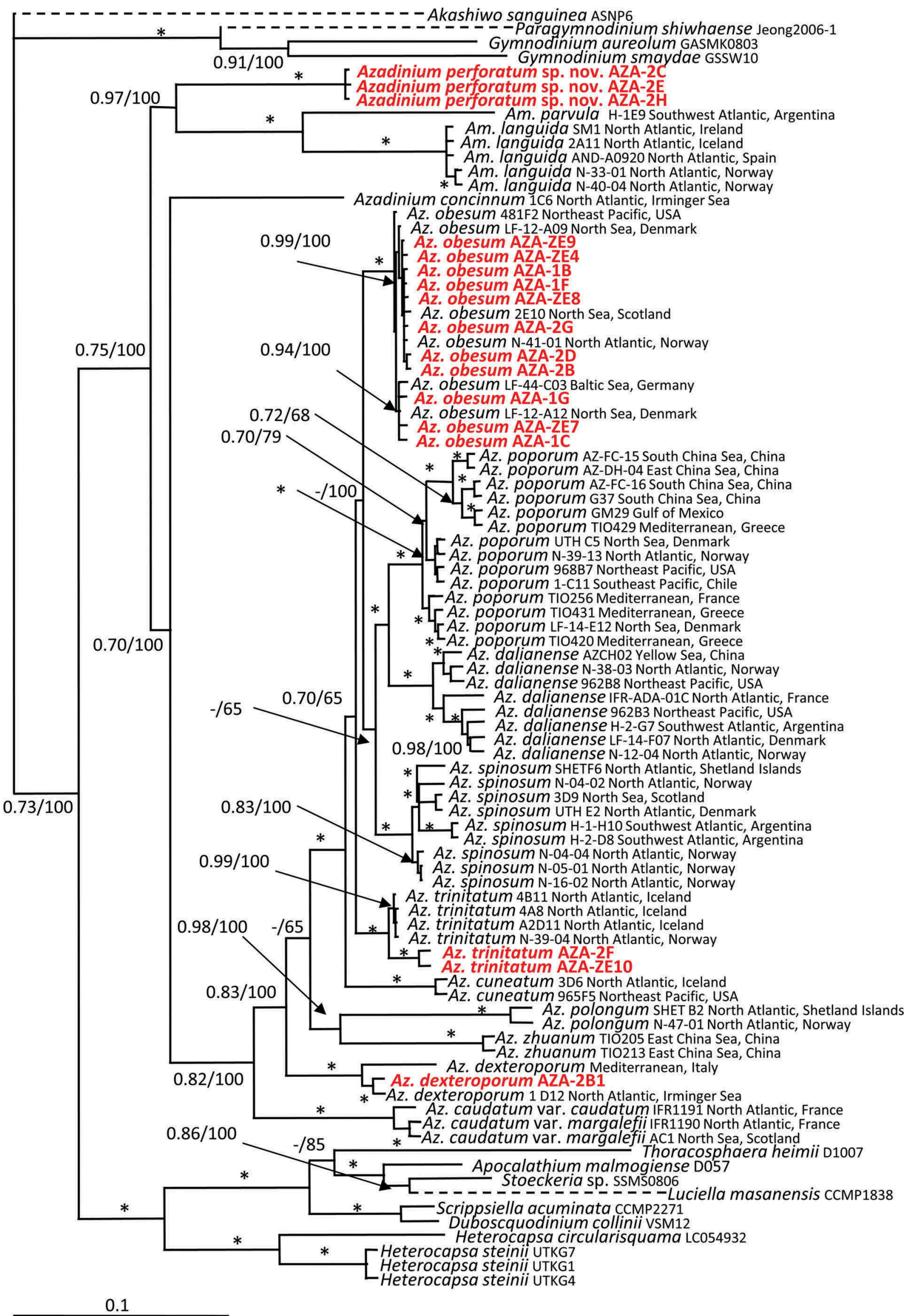

Fig. 73. Molecular phylogeny of Azadinium and Amphidoma inferred from concatenated SSU, partial LSU and ITS rDNA sequences using Bayesian inference (BI). New sequences of Azadinium perforatum, Az. dexteroporum, Az. trinitatum and Az. obesum indicated in red. Scale bar indicates number of nucleotide substitutions per site. Numbers on branches are statistical support values (left, Bayesian posterior probabilities; right, ML bootstrap support values). Asterisks (*) indicate maximal support ( $\mathrm{pp}=1.00$ in $\mathrm{BI}$ and bootstrap $=100 \%$ in $\mathrm{ML}$, respectively). Dashed lines indicate half-length. 

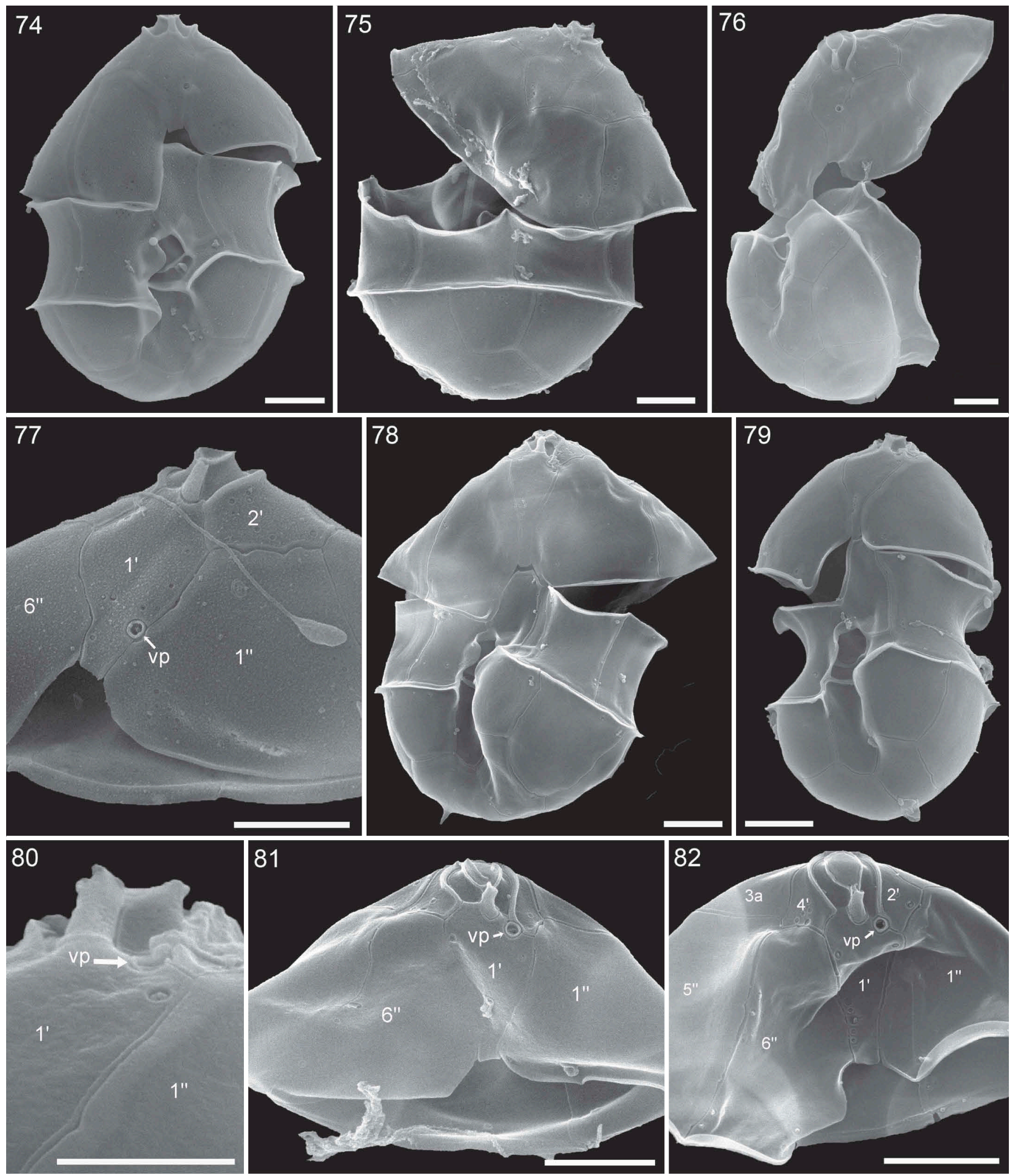

Figs 74-82. SEM, field sample from station 1. vp, ventral pore.

Fig. 74. Azadinium obesum in ventral view. Scale bar $=2 \mu \mathrm{m}$.

Fig. 75. Azadinium obesum in dorsal view. Scale bar $=2 \mu \mathrm{m}$.

Fig. 76. Unfolded thecae of $A z$. obesum allowing antapical/lateral view of hypotheca and ventral view of epitheca. Scale bar $=2 \mu \mathrm{m}$.

Fig. 77. Epitheca of Azadinium obesum in ventral view showing position of ventral pore. Scale bar $=2 \mu \mathrm{m}$.

Figs 78, 79. Azadinium trinitatum in ventral view. Note presence (Fig. 78) or absence (Fig. 79) of antapical spine. Scale bars $=2 \mu \mathrm{m}$.

Fig. 80. Detailed apical view of cell shown in Fig. 79 indicating position of ventral pore. Scale bar $=1 \mu \mathrm{m}$.

Figs 81, 82. Epitheca of Azadinium trinitatum in ventral view showing position of ventral pore and small lateral apical plates. Scale bars $=2 \mu \mathrm{m}$. 

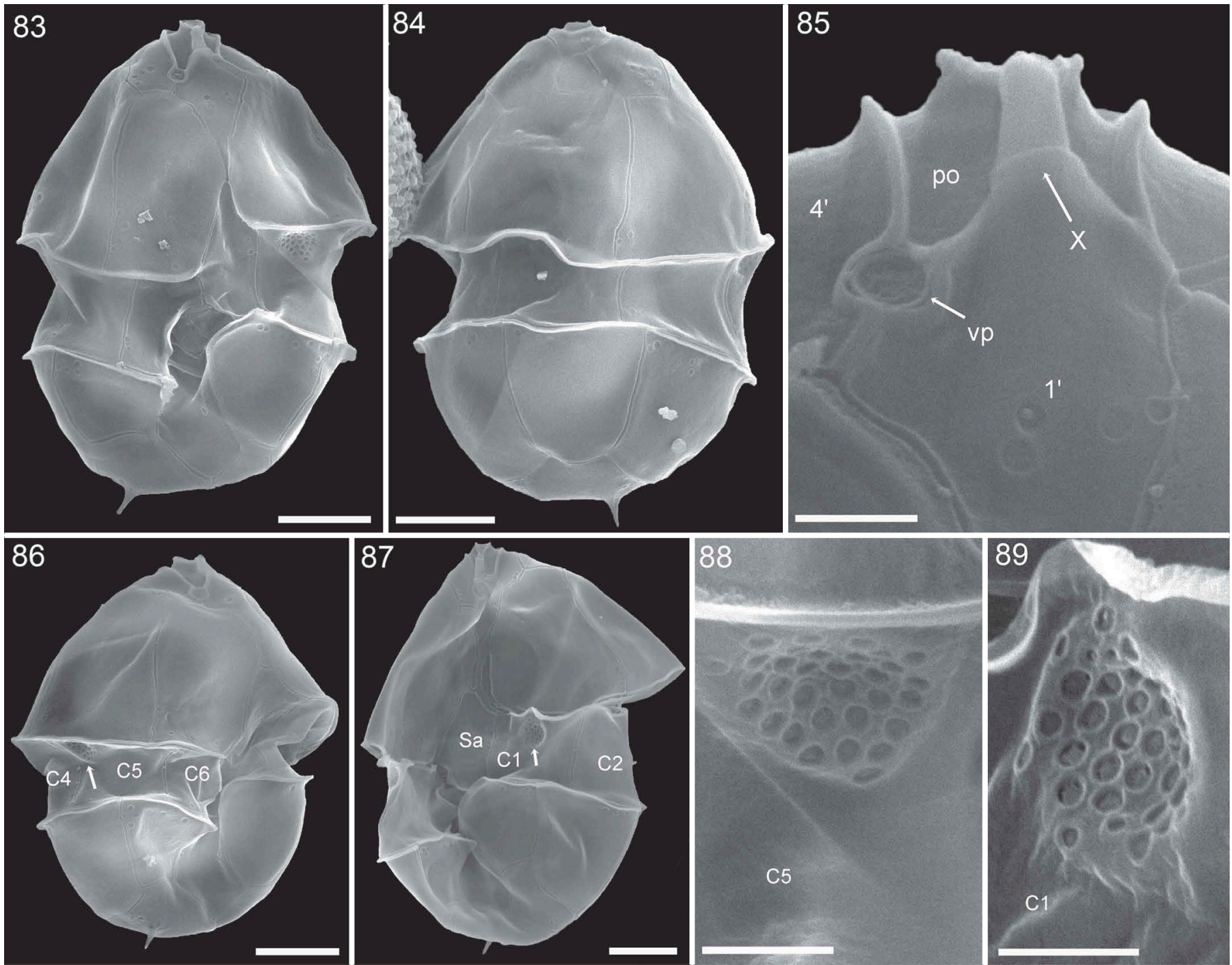

Figs 83-89. SEM, field sample from station 1, Azadinium dexteroporum. $X, X$-plate; vp, ventral pore; po, pore plate.

Fig. 83. Cell in ventral view. Scale bar $=2 \mu \mathrm{m}$.

Fig. 84. Cell in dorsal view. Scale bar $=2 \mu \mathrm{m}$.

Fig. 85. Detailed view of apical pore complex showing position of ventral pore. Scale bar $=0.5 \mu \mathrm{m}$.

Figs 86, 87. Cells in ventral view indicating position of pore fields (arrows) on cingular plates C5 (Fig. 86) and C1 (Fig. 87). Scale bars = $2 \mu \mathrm{m}$.

Figs 88, 89. Detailed view of cingular pore fields. Scale bars $=0.5 \mu \mathrm{m}$.

identified by shape, position of ventral pore, by lack of a spine, and the small anterior intercalary plates with the missing contact of plates 1a and 1" (Figs 74-77). Identifying specimens of Az. trinitatum (Figs 78-82) was difficult and required simultaneous visibility of both the ventral pore and the narrow apical plates to differentiate the species from $A z$. poporum and $A z$. dalianense. Most cells identified as $A z$. trinitatum lacked a spine (Fig. 79), but a single cell with a spine, likely representing Az. trinitatum, was observed (Fig. 78). Cells of Az. dexteroporum (Figs 83-89) were easily detected by their small size and peculiar position of the ventral pore. All cells attributed to $A z$. dexteroporum in dorsal view had a plane median intercalary plate $2 \mathrm{a}$ (Fig. 84). Cells of the field sample had a conspicuous roundish field of thecal pores on cingular plates $\mathrm{C} 1$ and $\mathrm{C5}$ (Figs 86-89). Specimens of the new species Az. perforatum (Figs 90-99) were regularly observed in the field sample, and these conformed to the morphological description of strain
AZA-2H. Just as for cells of the isolated strains, specimens of field samples were observed with fused dorsal apical plates $3^{\prime}$ and 2a (Figs 97-99).

In addition to species confirmed by established strains, additional species were identified. A single specimen of $A z$. spinosum was recorded based on presence of a spine and position of the ventral pore (Figs 100, 101). With ventral pore position resembling $A z$. spinosum, but with an elongated pore plate and large lateral apical plates, a few cells were identified as $A z$. polongum Tillmann (Figs 102, 103). Although appearing wrinkled and unfortunately blurred in SEM, two cells were identified as Am. languida based on the ventral pore position (Figs 104, 105) or by the presence of an antapical pore (Fig. 106). Moreover, a number of epithecal cell fragments were observed where apical plate number and arrangement conformed to $A z$. dalianense Z. Luo, H. Gu \& Tillmann, but where the position of the 

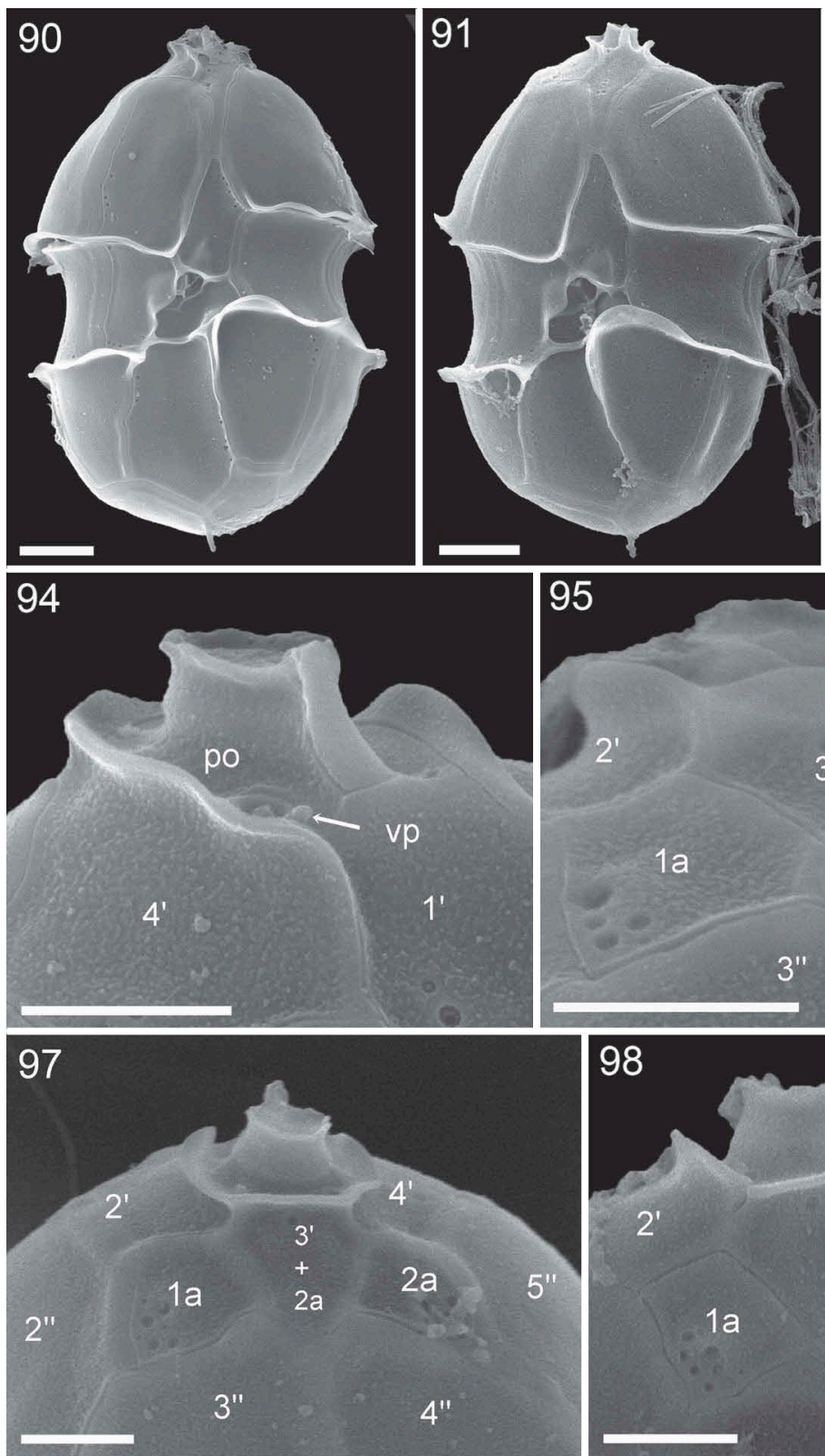
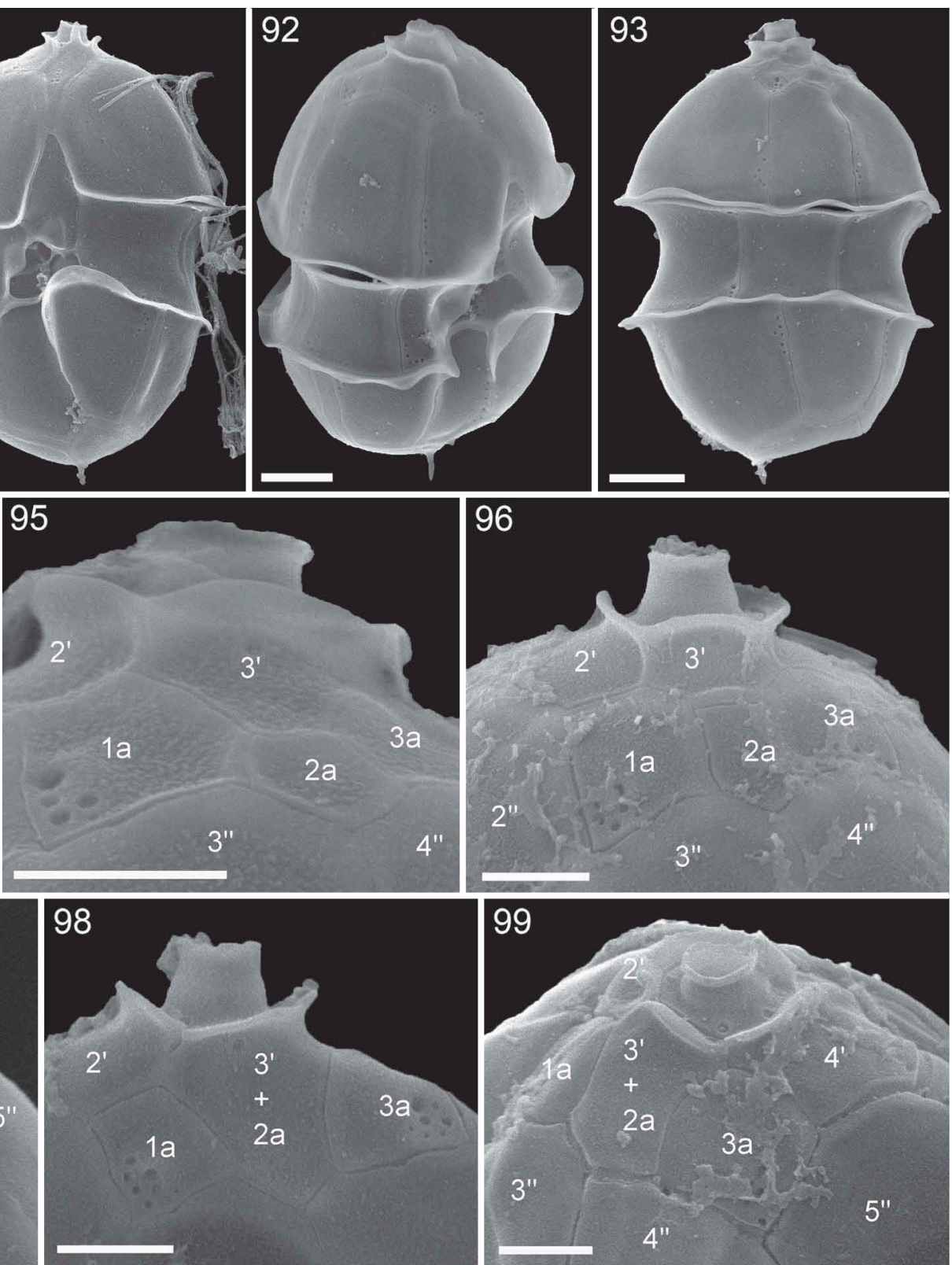

Figs 90-99. SEM, field sample of station 1, Azadinium perforatum sp. nov. vp, ventral pore; po, pore plate.

Figs 90, 91. Cells in ventral view. Scale bars $=2 \mu \mathrm{m}$.

Fig. 92. Cell in left lateral view. Scale bar $=2 \mu \mathrm{m}$.

Fig. 93. Cell in dorsal view. Scale bar $=2 \mu \mathrm{m}$.

Fig. 94. Detailed view of apical pore complex showing position of ventral pore. Scale bar $=1 \mu \mathrm{m}$.

Figs 95-99. Detailed dorsal view of apical area. Note suture between plates 3 ' and 2 a in Figs 95 and 96 , which is missing in $97-99$. Scale bars $=1 \mu$ m.

ventral pore was distinct, and located on the suture of plates $1^{\prime}$ and $2^{\prime}$ (Figs 107-109). Whole cell views of such cells were not available, and further observation is needed to characterise this potential new species.

\section{DISCUSSION}

In the first study of Amphidomataceae in subarctic areas (Tillmann et al. 2014a), seven randomly isolated strains represented as many as five species, three of which were newly described. With the present study and the description of a new Azadinium species, we demonstrate that the biodiversity of Amphidomataceae in the subarctic is remarkably large.

\section{Azadinium perforatum sp. nov.}

Morphological and molecular sequencing approaches clearly show that three of the newly established strains from the Labrador Sea represent a new species. The new taxon belongs to the genus Azadinium as it conforms to all features described as characteristic for the genus, including the plate pattern with four apical and three epithecal intercalary plates, both six post- and precingular plates, and two antapical plates 

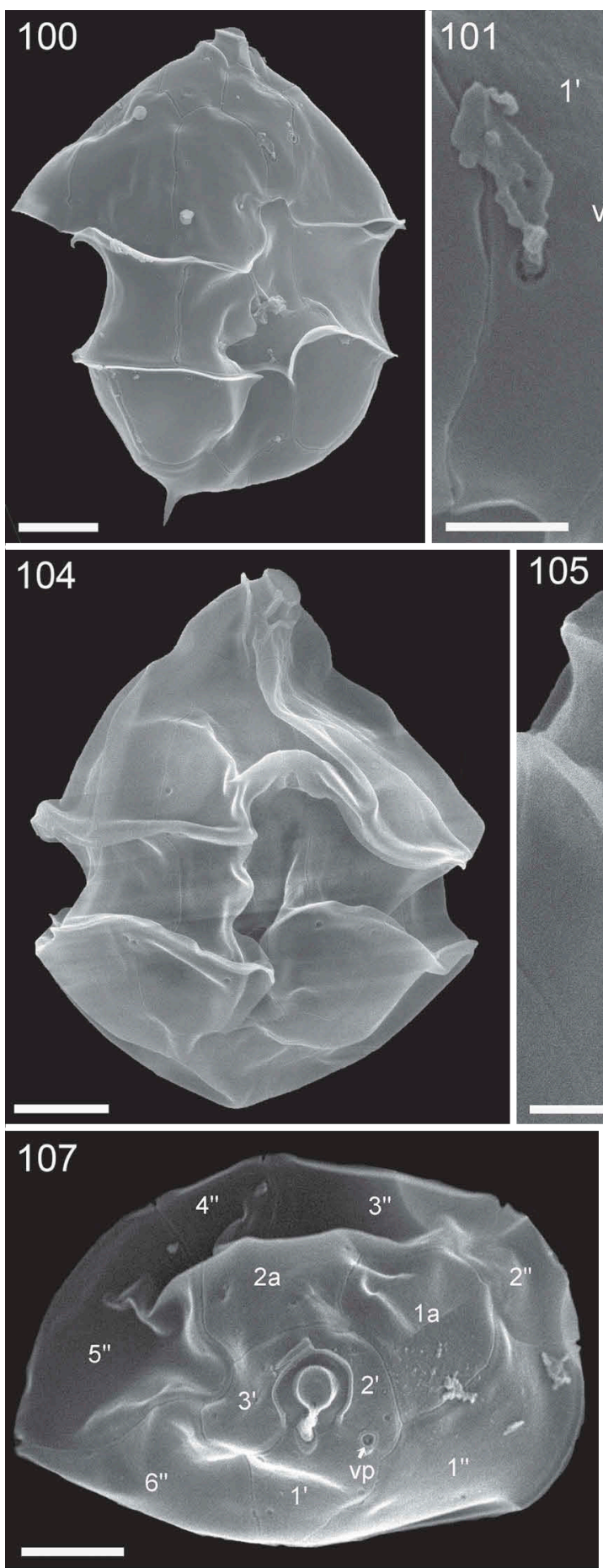
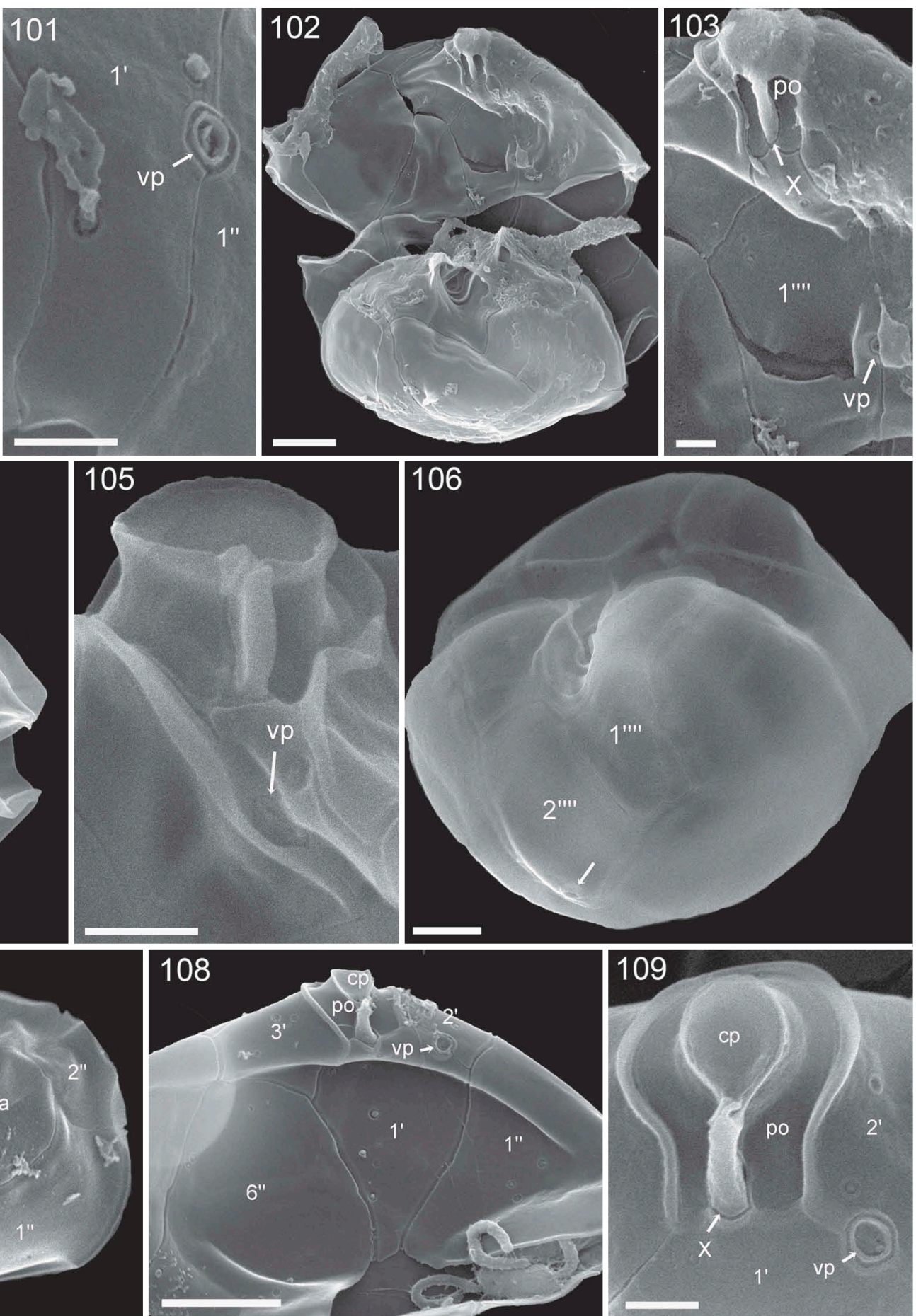

Figs 100-109. SEM, field sample of station 1. cp, cover plate; X, X-plate; vp, ventral pore; po, pore plate

Fig. 100. Azadinium spinosum in ventral view. Scale bar $=2 \mu \mathrm{m}$.

Fig. 101. Azadinium spinosum. Detailed view of the ventral area of the same cell shown in Fig. 100 to illustrate the position of the ventral pore. Scale bar $=0.5 \mu$ m.

Fig. 102. Azadinium polongum in ventral view. Scale bar $=2 \mu \mathrm{m}$.

Fig. 103. Detailed view of cell in Fig. 102 showing position of ventral pore and shape of the pore plate. Scale bar $=0.5 \mu \mathrm{m}$.

Fig. 104. Amphidoma languida in ventral view. Scale bar $=2 \mu \mathrm{m}$.

Fig. 105. Detailed view of cell in Fig. 104 showing position of ventral pore.

Fig. 106. Amphidoma languida in ventral/antapical view showing position of antapical pore (arrow). Scale bar $=2 \mu \mathrm{m}$.

Figs 107-109. Epithecae of Azadinium sp. in ventral/apical view. Note peculiar position of ventral pore located in middle of suture of plates 1 ' and 2', and presence of three apical plates and two anterior intercalary plates. Scale bars $=2 \mu \mathrm{m}(107,108)$ and $0.5 \mu \mathrm{m}(109)$.

(Tillmann et al. 2009). Although Az. perforatum resembles several other species of Azadinium in size and overall shape, it possesses a distinctive and unique combination of features, which unambiguously differentiate this species from others (Table 3). Previous work on Azadinium and Amphidoma emphasised that the position of the ventral pore (vp) is 
Table 3. Compilation of morphological features of species of Azadinium (including Az. perforatum) with a ventral pore located at the right side of the pore plate.

\begin{tabular}{|c|c|c|c|c|c|c|}
\hline & $\begin{array}{l}\text { Az. caudatum } \\
\text { var. margalefii }\end{array}$ & $\begin{array}{c}A z . \\
\text { dexteroporum }\end{array}$ & $\begin{array}{c}\text { Az. } \\
\text { concinnum }\end{array}$ & $\begin{array}{c}\text { Az. } \\
\text { luciferelloides }\end{array}$ & $\begin{array}{c}\text { Az. } \\
\text { zhuanum }\end{array}$ & $\begin{array}{c}\text { Az. } \\
\text { perforatum }\end{array}$ \\
\hline Length range $\mu \mathrm{m}$ (mean) & $25.0-42.1$ & $\begin{array}{c}7.0-10.0 \\
(8.5)\end{array}$ & $\begin{array}{c}8.0-11.5 \\
(9.5)\end{array}$ & $\begin{array}{c}9.4-14.1^{\dagger} \\
(11.1)\end{array}$ & $\begin{array}{c}16.8-21.6 \\
(18.5)\end{array}$ & $\begin{array}{c}15.3-20.0 \\
(18.0)\end{array}$ \\
\hline Width range $\mu \mathrm{m}$ (mean) & $18.4-30.0$ & $\begin{array}{c}5.0-8.0 \\
(6.2)\end{array}$ & $\begin{array}{c}5.6-8.3 \\
(6.6)\end{array}$ & $\begin{array}{c}6.6-10.1^{\dagger} \\
(7.9)\end{array}$ & $\begin{array}{c}12.5-18.8 \\
(14.8)\end{array}$ & $\begin{array}{c}9.9-14.4 \\
(12.6)\end{array}$ \\
\hline $\mathrm{L} / \mathrm{W}$ ratio & 1.2 & 1.4 & 1.4 & 1.4 & 1.3 & 1.5 \\
\hline Antapical projection & $\begin{array}{l}\text { short horn, long } \\
\text { spine }\end{array}$ & spine & spine & spine & spine & tiny spine \\
\hline Stalked pyrenoid & none & 1 & none & unknown & 1 & none \\
\hline $1^{\prime \prime}$ in contact $1 a$ & yes & yes & no & yes & yes & no \\
\hline $\begin{array}{l}\text { Number of apicals and } \\
\text { intercalary plates }\end{array}$ & 4,3 & 4,3 & 4,3 & 4,3 & 3,2 & 4,3 \\
\hline Ventral pore position & $\begin{array}{l}\text { pore plate, right } \\
\text { side, inside Po }\end{array}$ & $\begin{array}{c}\text { end of pore plate, right } \\
\text { side }\end{array}$ & pore plate, right side & $\begin{array}{l}\text { pore plate, } \\
\text { right side }\end{array}$ & $\begin{array}{l}\text { pore plate, } \\
\text { right side }\end{array}$ & pore plate, right side \\
\hline Pore plate symmetry & $\begin{array}{l}\text { suture to } 1 \text { ' almost } \\
\text { symmetric }\end{array}$ & $\begin{array}{c}\text { suture to } 1 \text { ' strongly } \\
\text { asymmetric, left side } \\
\text { more apical }\end{array}$ & $\begin{array}{l}\text { suture to } 1 \text { ' almost } \\
\text { symmetric }\end{array}$ & $\begin{array}{l}\text { suture to } 1^{\prime} \\
\text { almost } \\
\text { symmetric }\end{array}$ & $\begin{array}{l}\text { suture to } 1^{\prime} \\
\text { almost } \\
\text { symmetric }\end{array}$ & $\begin{array}{l}\text { suture to } 1 \text { ' almost } \\
\text { symmetric }\end{array}$ \\
\hline $\begin{array}{l}\text { Thecal pores on pore } \\
\text { plate }\end{array}$ & no & no & no & no & no & yes \\
\hline $\begin{array}{l}\text { Relative size of first and } \\
\text { last intercalary }\end{array}$ & small & small & very small & small & large & small \\
\hline $\begin{array}{l}\text { Relative size of apical } \\
\text { plates }\end{array}$ & medium & small & small & small & medium & medium \\
\hline $\begin{array}{l}\text { Size and arrangement of } \\
\text { precingular plates }\end{array}$ & $\begin{array}{c}\text { Plate } 3^{\prime \prime} \text { mid-dorsal, } \\
\text { plates } 2^{\prime \prime} \text { and } 4^{\prime \prime} \\
\text { small }\end{array}$ & Plate $3^{\prime \prime}$ mid-dorsal & $\begin{array}{c}\text { Large, symetrically } \\
\text { arranged, plate } 3^{\prime \prime} \text { and } 4 \text { " } \\
\text { mid-dorsal }\end{array}$ & $\begin{array}{l}\text { Plate } 3^{\prime \prime} \text { mid- } \\
\text { dorsal }\end{array}$ & $\begin{array}{l}\text { Plate } 3^{\prime \prime} \text { mid- } \\
\text { dorsal }\end{array}$ & $\begin{array}{c}\text { Large, symmetrically } \\
\text { arranged, plate, } 3^{\prime \prime} \text { and } 4 " \\
\text { mid-dorsal }\end{array}$ \\
\hline Records & $\begin{array}{l}\text { Mediterranean, } \\
\text { North Sea, Atlantic }\end{array}$ & $\begin{array}{c}\text { Mediterranean, North } \\
\text { Atlantic, } \\
\text { South Atlantic }\end{array}$ & North Atlantic & $\begin{array}{l}\text { South } \\
\text { Atlantic }\end{array}$ & $\begin{array}{l}\text { East China } \\
\text { Sea, } \\
\text { Yellow Sea }\end{array}$ & Labrador Sea \\
\hline Reference ${ }^{\ddagger}$ & $a, b$ & $c, d$ & e & $f$ & $\mathrm{~g}$ & This study \\
\hline
\end{tabular}

${ }^{\dagger}$ Based on SEM only. ${ }^{\ddagger}$ a, Nézan et al. (2012); b, Tillmann et al. (2014b); c, Percopo et al. (2013); d, Tillmann et al. (2015); e, Tillmann et al. (2014a); f, Tillmann \& Akselmann (2016); g, Luo et al. (2017)

diagnostic for species discrimination, although two new species of Amphidoma, Am. parvula Tillmann \& Gottschling and Am. alata Tillmann, lack such a ventral pore (Tillmann 2018a; Tillmann et al. 2018b). The amphidomatacean vp is larger than regular thecal pores, surrounded by a platelet-like structure, and has different and species-specific positions on the ventral part of the epitheca. With the vp on the right side of the pore plate, $A z$. perforatum is distinct from $A z$. spinosum, $A z$. obesum, $A z$. polongum, and $A z$. asperum Tillmann (vp on the left side of plate $1^{\prime}$ ), from $A z$. poporum, Az. dalianense, $A z$. trinitatum, $A z$. cuneatum (vp on left side of pore plate), and Az. caudatum var. caudatum (Halldal) Nézan \& Chomérat (vp on right side of plate 1'; see Table 3 in Tillmann et al. 2014a). Species that have a vp positioned similarly to $A z$. perforatum (on the cells' right side of the pore plate) are $A z$. caudatum var. margalefii (Rampi) Nézan \& Chomérat, $A z$. concinnum, $A z$. dexteroporum, Az. luciferelloides Tillmann \& Akselman, and $A z$. zhuanum Z.Luo, Tillmann \& H.Gu (Table 3). These species also have an antapical spine. In Az. perforatum, this spine was distinctly tiny, a feature consistent with field specimens (Figs 90-93). Notably, Az. perforatum is differentiated from all other Azadinium by its unique feature of thecal pores on the pore plate.

Although $A z$. perforatum is larger, it shares some morphological features with $A z$. concinnum, e.g., lack of a stalked pyrenoid, presence of small anterior intercalary plates, and lack of contact between the first precingular plate and the small first anterior intercalary plate. Otherwise, this feature is found only in Az. obesum and Az. cuneatum (Tillmann et al. 2014a). Moreover, precingular plates of both $A z$. perforatum and $A z$. concinnum are rather large and symmetrically arranged, and both plates $3 "$ and $4 "$ are in mid-dorsal position, also seen in species of Amphidoma (Dodge \& Saunders 1985; Tillmann et al. 2012; Tillmann 2018a). It is thus interesting to note that in previous phylogenetic analyses $A z$. concinnum had a rather basal position outside of all other Azadinium (Tillmann et al. 2019), not unlike the current phylogenetic analysis (Fig. 73). The seemingly large difference in epithecal plate arrangement (Amphidoma has six apical plates and no apical intercalary plate, whereas Azadinium species have only 3-4 apical plates but 2-3 apical intercalary plates) may also be explained by the fact that there is only one fewer epithecal plate in Amphidoma. It is conceivable that the intercalary plates of Azadinium are homologous to at least some of the apical plates in Amphidoma (Tillmann et al. 2014a). In this respect, it is important to note that for $A z$. perforatum a common plate variation was a fusion of apical plates $3^{\prime}$ and 2a (Fig. 34), and this deviation was also common among field specimens (Figs 97-99). Next to the number of apical and intercalary plates, another consistent (at least for species of Amphidoma studied by SEM) morphological difference between Azadinium and Amphidoma was recently highlighted (Tillmann 2018a): both differ in 
the detailed arrangement of the median sulcal area. For species of Amphidoma, the contact between plates Sa and C6 is long and covers almost the whole cingulum width, while for species of Azadinium this contact is more narrow, much less than one-third of cingulum width. In this respect, the sulcal area of both $A z$. concinnum and $A z$. perforatum are of the 'Azadinium' type.

While morphology of $A z$. concinnum and $A z$. perforatum, with their small apical and intercalary plates and the large and symmetrically arranged precingular plates, may indicate a similar and somewhat interim position of both species between Azadinium and Amphidoma, our phylogenetic analysis shows no close relationship between these species. The new $A z$. perforatum is placed outside of Azadinium as a sister clade to Amphidoma, whereas Az. concinnum is placed at the base within Azadinium but only moderately supported. The position of $A z$. perforatum thus indicates higher diversity within Amphidomataceae, potentially also at generic level. However, considering the morphological data and the currently unclear position of $A z$. concinnum, we argue that it is premature to erect a new genus for $A z$. perforatum. In the future, new species/strains of Amphidomataceae and/or new sequences of other marker genes may allow for a more differentiated evaluation of the generic diversity and evolution of the family.

In terms of symmetric precingular plates and relatively small apical and anterior intercalary plates, another similar species was described in 1959 as Gonyaulax parva from the Norwegian Sea and Iceland (Ramsfjell 1959). The plate pattern of this species corresponds to the plate tabulation of Azadinium and thus should be transferred to Azadinium at a later stage. The new species $A z$. perforatum differs from $G$. parva by its different shape (more elongated/slender for Az. perforatum than the broader G. parva) and by presence of the antapical spine.

The new species $A z$. perforatum is similar in shape to the sketch of a taxon from the Labrador Sea listed by Holmes (1956) as 'Goniaulax gracilis Schiller'. However, this name is just briefly mentioned as 'uncertain species' by Schiller (1935) without any description or diagnosis, and is thus not validly described (ICN Art. 38.1). Moreover, the description by Holmes indicates that the Labrador Sea cells are smaller (10-15 $\mu \mathrm{m}$ long) and have a different length:width ratio. In addition, his drawings indicate that the anterior sulcal plate is vaulted and extends close to the apex. Holmes' observations may thus refer to another undescribed small amphidomatacean species in the area. The name 'Goniaulax gracilis' sensu Schiller (and thus, likely a member of Amphidomataceae) is also linked to some pictures of small dinophytes in Bérard-Therriault et al. (1999; page 216, Fig. 90 $a-c, g, i, 1)$. The four LM images probably show species of Amphidomataceae, but no substantiating details are visible. One of the two SEM images (Fig. 90 i) probably represents a species of Amphidoma (Am. languida?), and the second cell (Fig. 90 l) is probably Azadinium, but with a distinct cell outline and a different development and position of the antapical spine than in Azadinium perforatum. 'Goniaulax gracilis' sensu Schiller is also mentioned briefly in a species list (without illustrations) by Smayda (1958) from Jan Mayen (North Atlantic) and by Hsiao (1983) from the Canadian Arctic, which may be interpreted as evidence that small species of Amphidomataceae are common in cold-water, northern plankton communities.

\section{Amphidomataceae in Labrador Sea and coastal Greenland waters}

Positive hits of the SYBR Green PCR assay indicate that Amphidomataceae are widely distributed in the study area, covering quite different regions including the open, deep Labrador Sea, inland fjord areas such as Godthaab Fjord, Disko Bay and the two northernmost stations. The amphidomatacean SYBR Green PCR assay was not performed quantitatively but relatively high $\mathrm{Ct}$ values [cycle threshold $(\mathrm{Ct})>$ 27] indicate a rather low cell abundance for all Greenland stations. Slightly lower Ct values (Ct: 27-30) were observed inside Disko Bay, indicating higher densities than in stations further outside (Ct: 30-33). Generally, low abundance corresponds to a lack of firm identification of amphidomatacean cells during quantitative Utermöhl counts for these stations. A lack of microscopic confirmation does not contradict low PCR signals as the microscopy sample volume was limited $(50 \mathrm{ml})$ and single amphidomatacean cells might easily go unnoticed in the larger group of small unidentified dinoflagellates. Thus, the data underline the advantage of molecular detection at low abundance of this small and inconspicuous group of microalgae.

In the whole Greenland area, only two stations were positive with the species-specific qPCR assays, and both indicate the presence of low background levels of Azadinium poporum. This species has a wide distribution in the Mediterranean Sea, the Pacific and the Atlantic (Tillmann 2018b). The northern record reported here needs to be confirmed by more direct methods, as false-positive qPCR reactions cannot be ruled out. Nevertheless, in silico sequence comparison of all other known amphidomatacean species with $A z$. poporum primers and probe (Wietkamp, unpublished) identified at least seven base pair mismatch. This underlines the high specificity of the assay, and indicates that risk of a false-positive cross-reaction is low.

The first station in the central Labrador Sea was distinct from the more coastal Greenland stations and had a total plankton biomass approximately three times higher than the Greenland station with the highest biomass (estimated from Utermöhl counts and volume-carbon conversion, unpublished data). In contrast to most coastal Greenlandic stations, diatoms in the central Labrador Sea were of low abundance (absolute and relative) and comprised only $0.6 \%$ of total plankton biomass. Plankton at station 1 was dominated by small $(<20 \mu \mathrm{m})$ unidentified flagellates $\left(1.7 \times 10^{6} \mathrm{l}^{-1}\right)$. Most intriguing was the dominance of a c. $25 \mu \mathrm{m}$ large unidentified haptophyte with a short, stiff haptonema and the very unusual presence of $c .20$ small chloroplasts. Dinoflagellates made up about one-third of the biomass at station 1 with a high density of small athecate species, most of which could not be identified to species level. In contrast to the coastal Greenlandic stations, a significant number of toxigenic cells of Dinophysis acuminata $\left(330 \mathrm{l}^{-1}\right)$ were present and confirmed the presence of relatively high levels of pectenotoxin-2 (Krock, unpublished). The most abundant phototrophic dinoflagellate was a yet undetermined small 
(10-15 $\mu \mathrm{m})$ Prorocentrum $\left(64 \times 10^{3}\right.$ cells $\left.\mathrm{l}^{-1}\right)$. Within this diverse community, Amphidomataceae were fairly abundant (9.2 $\times 10^{3}$ cells $1^{-1}$ ) as estimated by quantitative LM, and confirmed by an exceptionally strong signal of the SYBR Green PCR assay (Ct $19.85 \pm 0.06, \mathrm{n}=3$ ). The first station in the central Labrador Sea was the only station where the toxigenic species Am. languida was recorded by the specific qPCR assay, yielding an abundance of $c .120$ cells $1^{-1}$, which is in the lower range of cell densities determined for this species along the Danish coast (Wietkamp et al. 2019b). In any case, amphidomatacean abundance in the central Labrador Sea in June is lower than bloom concentrations of Amphidomataceae that may be as high as $10^{6}$ cells $1^{-1}(A z$. polongum bloom in Peru; Tillmann et al. 2017) or $3 \times 10^{5}$ to $1 \times 10^{7}$ cells $1^{-1}$ (Amphidomataceae spring bloom densities on Argentine Shelf; Akselman \& Negri 2012; Tillmann et al. 2019).

Based on both, field-sample-SEM and the amphidomatacean strains established from station 1, a large diversity of Amphidomataceae in the central Labrador Sea is evident. Next to strain-based records of $A z$. obesum, Az. trinitatum, $A z$. dexteroporum, and $A z$. perforatum, SEM indicates the presence of Az. spinosum, Am. languida, and Az. polongum. Moreover, another probably yet undescribed species is present whose apical plate number and arrangement conform to $A z$. dalianense (Luo et al. 2013), but the position on the ventral pore is different (Figs 107-109). However, no whole-cell views were obtained, and more studies are needed for a more detailed morphological description of this potentially new species.

The ability to establish multiple strains of $A z$. obesum, $A z$. trinitatum and $A z$. perforatum indicates that these are the dominant Amphidomataceae in the summer community of the Labrador Sea. Azadinium obesum is known from the North Atlantic Ocean (Tillmann et al. 2010, 2018a) and Az. trinitatum is known from the Iceland area (Tillmann et al. 2014a); thus, their presence in the Labrador Sea was not unexpected.

The new Labrador strains of $A z$. trinitatum form a wellsupported sister clade to the Icelandic strains of the species. Uncorrected genetic distance of ITS rDNA between both clades is relatively low (0.006, Table 2$)$, but nevertheless indicates significant intraspecific variability in Az. trinitatum. This is supported by the fact that the new strains lack an antapical spine, which is present in Icelandic populations (Tillmann et al. 2014a).

The Labrador Sea record of Az. dexteroporum, together with a previously established strain from the Irminger Sea (Tillmann et al. 2015), confirm the presence of this species in the subarctic region. The new Labrador Sea strain differs significantly from the Mediterranean type material in terms of sequence data (ITS rDNA genetic distance $=0.038$, Table 2 ) and by the presence of a plain median intercalary plate; this plate is distinctly concave in the Mediterranean strain (Percopo et al. 2013). All of these facts indicate cryptic diversity for $A z$. dexteroporum, and taxonomic assessment of this diversity should be the objective of future research.

One single cell, most likely representing Az. spinosum, was identified in the SEM sample from station 1, but the $A z$. spinosum-specific qPCR assay was negative. This might be explained by abundance below the qPCR detection limit of approx. 0.5 cells $1^{-1}$. Moreover, recent studies have revealed significant intraspecific variability in $A z$. spinosum in terms of rDNA sequence data (Tillmann et al. 2018a, 2019), which likely affects the primer/probe binding efficiency. If $A z$. spinosum in the Labrador Sea is from a different ribotype than that of the $A z$. spinosum strains/ribotype used to design the assay, the assay efficiency and thus detection and quantification of the qPCR method would be affected.

\section{Azaspiracids}

No azaspiracids were detected in discrete plankton samples from the study area. A lack of AZA at the first station, where a cell density of 120 cells $1^{-1}$ of the toxigenic Am. languida was determined by qPCR, may be explained by the detection limit of the chemical method. Combining the LOD of the AZA measurements $\left(10 \mathrm{pg} \mathrm{l}^{-1}\right)$ and the highest AZA cell quota of $\mathrm{Am}$. languida reported in the literature, of $100 \mathrm{fg}^{\text {cell }}{ }^{-1}$ (Wietkamp et al. 2019b), yields a 'cell detection limit' of 100 cells $\mathrm{l}^{-1}$, which is only slightly lower than the qPCR-determined abundance. Absence of AZA in field samples also agrees with the lack of AZA production of all newly established strains of Az. obesum, $A z$. trinitatum, $A z$. dexteroporum and $A z$. perforatum. For $A z$. obesum and $A z$. trinitatum, this confirms previous study results that neither species are AZA producers (Tillmann et al. 2014a; Wietkamp et al. 2019b). AZA has unambiguously been described for type strains of $A z$. dexteroporum from the Mediterranean Sea (Rossi et al. 2017). However, another strain (1-D12) isolated from the subarctic Irminger Sea lacked AZA (Tillmann et al. 2015). Absence of AZA in the new Labrador Sea strains confirms this finding and suggests non-toxigenity of $A z$. dexteroporum from the North Atlantic Ocean. A comparable situation with both producing and non-producing strains, with significant levels of sequence differences, can be seen in $A z$. poporum (Luo et al. 2018; Wietkamp et al. 2019b) and $A z$. spinosum (Tillmann et al. 2019). None of the high biomass samples of all three clonal strains of $A z$. perforatum revealed AZA, indicating that this new species likely does not produce AZA. However, with the aforementioned strain variability in $A z$. dexteroporum and the recently discovered intraspecific variability in AZA expression for Az. poporum and Az. spinosum (Luo et al. 2018; Tillmann et al. 2019; Wietkamp et al. 2019b), more studies and strains of $A z$. perforatum are needed for confirmation. In any case, with 10 non-toxigenic species versus four known AZA producers, it is evident that AZA production within Amphidomataceae is the exception rather than the rule.

Azaspiracids were also lacking in the SPATT samples from the FerryBox flow-through system. SPATT samplers specifically adsorb large, lipophilic molecules such as AZA (Fux et al. 2009; MacKenzie et al. 2004), and with long-term deployment (here for about 1 week) allow for integrative sampling to detectminute amounts of these molecules. A lack of AZA detection in SPATT samples thus strengthens the conclusion that abundance and significance of toxigenic Amphidomataceae in JuneJuly for the western Greenland area are low.

\section{ACKNOWLEDGEMENTS}

We thank chief scientist Oliver Zielinski, Captain Maaß and the crew of $R V$ Maria S. Merian for assistance and logistical support with the collection of field material used in this study. Anne Müller and 
Thomas Max are acknowledged for their help with on-board work during the cruise and especially for DNA and toxin extraction. Torben Krohn (AWI) kindly assisted with AZA sample preparation and analysis. Thanks to Marc Gottschling (Uni München) for helpful discussions.

\section{FUNDING}

This work was supported by the PACES research program of the Alfred Wegener Institute as part of the Helmholtz Foundation initiative in Earth and Environment, and by the German Ministry for Education and Research (project RIPAZA) under grant number 03F0763A.

\section{ORCID}

Haifeng Gu (D) http://orcid.org/0000-0002-2350-9171

\section{REFERENCES}

Akselman R. \& Negri R.M. 2012. Blooms of Azadinium cf. spinosum Elbrächter et Tillmann (Dinophyceae) in northern shelf waters of Argentina, Southwestern Atlantic. Harmful Algae 19: 30-38. DOI: 10.1016/j.hal.2012.05.004

Bérard-Therriault L., Poulin M. \& Bossé L. 1999. Guide d'identification $d u$ phytoplancton marin de l'estuaire et du golfe de Saint-Laurent incluant également certaines protozoaires. Publication spéciale canadienne des sciences halieutiques et aquatiques 128. NRC Research Press, Ottawa, Canada. 387 pp.

Boc A., Diallo A.B. \& Makarenkov V. 2012. T-REX: a web server for inferring, validating and visualizing phylogenetic trees and networks. Nucleic Acids Research 40: 573-579. DOI: 10.1093/nar/gks485.

Brandt K. \& Apstein C. [eds] 1908. Nordisches Plankton. Lipsius \& Tischer, Kiel, Leipzig, Germany. 356pp.

Cleve P.T. 1873. On diatoms of the Arctic Sea. Bihang Kongelige Svenska Vetenskapelige Akademie Handlingar 1(13): 1-28.

Cleve P.T. \& Grunow A. 1880. Beiträge zur Kenntniss der arktischen Diatomeen. Kongiga Svenska Vetenskaps-Akademiens Handlingar 17: $1-122$.

Dodge J.D. \& Saunders R.D. 1985. An SEM study of Amphidoma nucula (Dinophyceae) and description of the thecal plates in A. caudata. Archiv Für Protistenkunde 129: 89-99. DOI: 10.1016/S0003-9365(85) 80012-9.

Ehrenberg C.G. 1843. Über neue Anschauungen des kleinsten nördlichen Polarlebens. Deutsche Akademie Der Wissenschaften $\mathrm{Zu}$ Berlin Monatsberichte 1843: 522-529.

Elferink S., Neuhaus S., Wohlrab S., Toebe K., Voß D., Gottschling M., Lundholm N., Krock B., Koch B.P., Zielinski O. et al. 2017. Molecular diversity patterns among various phytoplankton size-fractions in West Greenland in late summer. Deep-Sea Research Part I 121: 54-69. DOI: 10.1016/j.dsr.2016.11.002.

Forootan A., Sjöback R., Björkman J., Sjögreen B., Linz L. \& Kubista M. 2017. Methods to determine limit of detection and limit of quantification in quantitative real-time PCR (qPCR). Biomolecular Detection and Quantification 12: 1-6. DOI: 10.1016/j.bdq.2017.04.001.

Fux E., Biré R. \& Hess P. 2009. Comparative accumulation and composition of lipophilic marine biotoxins in passive samplers and in mussels (M. edulis) on the west coast of Ireland. Harmful Algae 8: 523-537. DOI: 10.1016/j.hal.2008.10.007.

Gran H.H. 1929. Quantitative plankton investigations carried out during the expedition with the "Michael Sars", July - Sept. 1924. Rapports Et Procès-verbaux Des Réunions/Conseil Permanent International pour l'Exploration de la Mer 56: 1-50.

Grontved J. \& Seidenfaden G. 1938. The phytoplankton of the waters west of Greenland. Meddelelser Om Grønland 82(5): 1-380.

Hall T. 1999. BioEdit: a user-friendly biological sequence alignment editor and analysis program for windows 95/98/NT. Nucleic Acids Symposium Series 41: 95-98.
Halldal P. 1953. Phytoplankton investigations from weather Ship M in the Norwegian Sea, 1948-49. Hvalrådets Skrifter 38: 1-91.

Hess P., McCarron P., Krock B., Kilcoyne J. \& Miles C.O. 2014. Azaspiracids: chemistry, biosynthesis, metabolism, and detection. In: Seafood and freshwater toxins, (Ed. by L.M. Botana), pp. 799-821. CRC Press, Boca Raton, Florida, USA.

Holmes R.W. 1956. The annual cycle of phytoplankton in the Labrador Sea, 1950-1951. Bulletin of the Bingham Oceanographic Collection 16: 1-74.

Hsiao S.I.C. 1983. A checklist of marine phytoplankton and sea ice microalgae recorded from Arctic Canada. Nova Hedwigia 37: 225-313.

Katoh K. \& Standley D.M. 2013. MAFFT multiple sequence alignment software version 7: improvements in performance and usability. Molecular Biology and Evolution 30: 772-780. DOI: 10.1093/molbev/mst010.

Keller M.D., Selvin R.C., Claus W. \& Guillard R.R.L. 1987. Media for the culture of oceanic ultraphytoplankton. Journal of Phycology 23: 633-638. DOI: 10.1111/j.1529-8817.1987.tb04217.x.

Kilias E., Kattner G., Wolf C., Frickenhaus S. \& Metfies K. 2014. A molecular survey of protist diversity through the central Arctic Ocean. Polar Biology 37: 1271-1287. DOI: 10.1007/s00300-014-1519-5.

Kilias E., Wolf C., Nöthig E.-M., Peeken I. \& Metfies K. 2013. Protist distribution in the western Fram Strait in summer 2010 based on 454-pyrosequencing of 18S rDNA. Journal of Phycology 49: 996-1010. DOI: $10.1111 /$ jpy.12109.

Lebour M.V. 1925. The dinoflagellates of the northern seas. The Marine Biological Association of the United Kingdom, Plymouth, UK. 250 pp.

Luo Z., Gu H., Krock B. \& Tillmann U. 2013. Azadinium dalianense, a new dinoflagellate from the Yellow Sea, China. Phycologia 52: 625-636. DOI: 10.2216/13-178.1.

Luo Z., Krock B., Giannakourou A., Venetsanopoulou A., Pagou K., Tillmann U. \& Gu H. 2018. Sympatric occurrence of two Azadinium poporum ribotypes in the eastern Mediterranean Sea. Harmful Algae 78: 75-85. DOI: 10.1016/j.hal.2018.08.003.

Luo Z., Krock B., Mertens K.N., Nézan E., Chomérat N., Bilien G., Tillmann U. \& Gu H. 2017. Adding new pieces to the Azadinium (Dinophyceae) diversity and biogeography puzzle: non-toxigenic Azadinium zhuanum sp. nov. from China, toxigenic A. poporum from the Mediterranean, and a non-toxigenic $A$. dalianense from the French Atlantic. Harmful Algae 66: 65-78. DOI: 10.1016/j.hal.2017.05.001.

MacKenzie L., Beuzenberg V., Holland P., McNabb P. \& Selwood A.I. 2004. Solid phase adsorption toxin tracking (SPATT): a new monitoring tool that simulates the biotoxin contamination of filter feeding bivalves. Toxicon 44: 901-918. DOI: 10.1016/j.toxicon.2004.08.020.

Medinger R., Nolte V., Pandey R.V., Jost S., Ottenwaelder B., Schloetterer C. \& Boenigk J. 2010. Diversity in a hidden world: potential and limitation of next-generation sequencing for surveys of molecular diversity of eucaryotic microorgnasisms. Molecular Ecology 19: 32-40.

Metfies K., Von Appen W.J., Kilias E., Nicolaus A. \& Nöthig E.M. 2012. Biogeography and photosynthetic Biomass of Arctic Marine Pico-Eukaroytes during Summer of the Record Sea Ice Minimum 2012. PloS One 11: e0148512.

Nézan E., Tillmann U., Bilien G., Boulben S., Chèze K., Zentz F., Salas R. \& Chomérat N. 2012. Taxonomic revision of the dinoflagellate Amphidoma caudata: transfer to the genus Azadinium (Dinophyceae) and proposal of two varieties, based on morphological and molecular phylogenetic analyses. Journal of Phycology 48: 925-939. DOI: 10.1111/j.1529-8817.2012.01159.x.

Nylander J.A., Wilgenbusch J.C., Warren D.L. \& Swofford D.L. 2008. AWTY (are we there yet?): a system for graphical exploration of MCMC convergence in Bayesian phylogenetics. Bioinformatics 24: 581-583. DOI: 10.1093/bioinformatics/btm388.

Percopo I., Siano R., Rossi R., Soprano V., Sarno D. \& Zingone A. 2013. A new potentially toxic Azadinium species (Dinophyceae) from the Mediterranean Sea, A. dexteroporum sp. nov. Journal of Phycology 49: 950-966. DOI: 10.1111/jpy.12104.

Posada D. 2008. ModelTest: Phylogenetic model averaging. Molecular Biology and Evolution 25: 1253-1256. DOI: 10.1093/molbev/msn083.

Poulin M., Daugbjerg N., Gradinger R., Ilyash L., Ratkova T. \& Von Quillfeldt C. 2011. The pan-Arctic biodiversity of marine pelagic and sea-ice unicellular eukaryotes: a first-attempt assessment. Marine Biodiversity 41: 13-28. DOI: 10.1007/s12526-010-0058-8. 
Preston-Thomas H. 1990. The international temperature scale of 1990 (ITS-90). Metrologia 27: 3-10. DOI: 10.1088/0026-1394/27/1/002.

Ramsfjell E. 1959. Two new phytoplankton species from the Norwegian Sea, the diatom Coscinosira poroseriata, and the dinoflagellate. Gonyaulax Parva. Nytt Magasin for Botanikk 7: 175-177.

Ronquist F. \& Huelsenbeck J.P. 2003. MrBayes 3: Bayesian phylogenetic inference under mixed models. Bioinformatics 19: 1572-1574. DOI 10.1093/bioinformatics/btg180.

Rossi R., Dell'Aversano C., Krock B., Ciminiello P., Percopo I., Tillmann U., Soprano V. \& Zingone A. 2017. Mediterranean Azadinium dexteroporum (Dinophyceae) produces AZA-35 and six novel azaspiracids: a structural study by a multi-platform mass spectrometry approach. Analytical and Bioanalytical Chemistry 409: 1121-1134. DOI: 10.1007/s00216-016-0037-4.

Schiller J. 1935. Dinoflagellatae (Peridineae) in monographischer Behandlung. In: Dr. L. Rabenhorst's Kryptogamen-Flora von Deutschland, Österreich und der Schweiz, (Ed. by L. Rabenhorst), pp. 1-320. Akademische Verlagsgesellschaft, Lepzig, Germany.

Schlitzer R. 2018. Ocean data view. https://odv.awi.de.

Smayda T.J. 1958. Phytoplankton studies around Jan Mayen Island March - April, 1955. Nytt Magasin for Botanikk 6: 75-96.

Smith K.F., Rhodes L., Harwood D.T., Adamson J., Moisan C., Munday R. \& Tillmann U. 2016. Detection of Azadinium poporum in New Zealand: The use of molecular tools to assist with species isolations. Journal of Applied Phycology 28: 1125-1132. DOI: 10.1007/s10811-015-0667-5.

Stamatakis A. 2006. RAxML-VI-HPC: Maximum likelihood-based phylogenetic analyses with thousands of taxa and mixed models. Bioinformatics 22: 2688-2690. DOI: 10.1093/bioinformatics/btl446.

Swofford D.L. 2002. PAUP*: phylogenetic analysis using parsimony $\left({ }^{*}\right.$ and other methods), version 4.0b10. Sinauer Associates, Sunderland, Massachusetts, USA.

Throndsen J., Hasle G.R. \& Tangen K. 2007. Phytoplankton of Norwegian coastal waters. Almater Forlag AS, Oslo, Norway. 343 pp.

Tillmann U. 2018a. Electron microscopy of a 1991 spring plankton sample from the Argentinean shelf reveals the presence of four new species of Amphidomataceae (Dinophyceae). Phycological Research 66: 269-290. DOI: 10.1111/pre.12225.

Tillmann U. 2018b. Amphidomataceae. In: Harmful Algae Blooms, a compendium desk reference, (Ed. by S.E. Shumway, J.A. Burkholder \& S.L. Morton), pp. 575-582. Wiley, Hoboken, New Jersey, USA.

Tillmann U. \& Akselman R. 2016. Revisiting the 1991 algal bloom in shelf waters off Argentina: Azadinium luciferelloides sp. nov. (Amphidomataceae, Dinophyceae) as the causative species in a diverse community of other amphidomataceans. Phycological Research 64: 160-175. DOI: 10.1111/pre.2016.64.issue-3.

Tillmann U., Edvardsen B., Krock B., Smith K.F., Paterson R.F. \& Voß D. 2018a. Diversity, distribution, and azaspiracids of Amphidomataceae (Dinophyceae) along the Norwegian coast. Harmful Algae 80: 15-34. DOI: 10.1016/j.hal.2018.08.011.

Tillmann U., Elbrächter M., John U., Krock B. \& Cembella A. 2010. Azadinium obesum (Dinophyceae), a new nontoxic species in the genus that can produce azaspiracid toxins. Phycologia 49: 169-182. DOI: 10.2216/PH09-35.1.

Tillmann U., Elbrächter M., Krock B., John U. \& Cembella A. 2009. Azadinium spinosum gen. et sp. nov. (Dinophyceae) identified as a primary producer of azaspiracid toxins. European Journal of Phycology 44: 63-79. DOI: 10.1080/09670260802578534.

Tillmann U., Gottschling M., Guinder V. \& Krock B. 2018b. Amphidoma parvula (Amphidomataceae), a new planktonic dinophyte from the
Argentine Sea. European Journal of Phycology 53: 14-28. DOI: 10.1080/09670262.2017.1346205.

Tillmann U., Gottschling M., Krock B., Smith K.F. \& Guinder V. 2019. High abundance of Amphidomataceae (Dinophyceae) during the 2015 spring bloom of the Argentinean Shelf and a new, non-toxigenic ribotype of Azadinium spinosum. Harmful Algae 84: 244-260. DOI: 10.1016/j. hal.2019.01.008.

Tillmann U., Gottschling M., Nézan E. \& Krock B. 2015. First record of Azadinium dexteroporum and Amphidoma languida (Amphidomataceae, Dinophyceae) from the Irminger Sea off Iceland. Marine Biodiversity Records 8: 1-11. DOI: 10.1017/S1755267215001128.

Tillmann U., Gottschling M., Nézan E., Krock B. \& Bilien G. 2014a. Morphological and molecular characterization of three new Azadinium species (Amphidomataceae, Dinophyceae) from the Irminger Sea. Protist 165: 417-444. DOI: 10.1016/j.protis.2014.04.004.

Tillmann U., Krock B. \& Taylor B. 2014b. Azadinium caudatum var. margalefii, a poorly known member of the toxigenic genus Azadinium (Dinophyceae). Marine Biology Research 10: 941-956. DOI: 10.1080/ 17451000.2013.866252.

Tillmann U., Salas R., Gottschling M., Krock B., O'Driscoll D. \& Elbrächter M. 2012. . Amphidoma languida sp. nov. (Dinophyceae) reveals a close relationship between Amphidoma and Azadinium. Protist 163: 701-719. DOI: 10.1016/j.protis.2011.10.005.

Tillmann U., Sánchez-Ramírez S., Krock B. \& Bernales-Jiménez A. 2017. A bloom of Azadinium polongum in coastal waters off Peru. Revista De Biología Marina Y Oceanografía 52: 591-610. DOI: 10.4067/S071819572017000300015 .

Toebe K., Joshi A.R., Messtorff P., Tillmann U., Cembella A. \& John U. 2013. Molecular discrimination of taxa within the dinoflagellate genus Azadinium, the source of azaspiracid toxins. Journal of Plankton Research 35: 225-230. DOI: 10.1093/plankt/fbs077.

Twiner M., Hess P. \& Doucette G.J. 2014. Azaspiracids: toxicology, pharmacology, and risk assessment. In: Seafood and freshwater toxins, (Ed. by L.M. Botana), pp. 823-855. CRC Press, Boca Raton, Florida, USA.

Wassmann P., Duarte C.M., Agustí S. \& Sejr M.K. 2011. Footprints of climate change in the Arctic marine ecosystem. Global Change Biology 17: 1235-1249. DOI: $10.1111 / \mathrm{gcb} .2010 .17$.issue-2.

Wietkamp S., Krock B., Gu H., Voß D., Klemm K. \& Tillmann U. $2019 b$. Occurrence and distribution of Amphidomataceae (Dinophyceae) in Danish coastal waters of the North Sea, the Limfjord, and the Kattegat/ Belt area. Harmful Algae 88: 101637. DOI: 10.1016/j.hal.2019.101637.

Wietkamp S., Tillmann U., Clarke D. \& Toebe K. 2019a. Molecular determination and quantification of the toxigenic dinoflagellate Amphidoma languida (Amphidomataceae, Dinophyceae). Journal of Plankton Research 41: 101-113. DOI: 10.1093/plankt/fby052.

Wolf C., Kilias E. \& Metfies K. 2015. Protists in the polar regions: comparing occurrence in the Arctic and Southern Oceans using pyrosequencing. Polar Research 34: 23225. DOI: 10.3402/polar. v34.23225.

Xiao X., Sogge H., Lagesen K., Tooming-Klunderud A., Jakobsen K.S. \& Rohrlack T. 2014. Use of high throughput sequencing and light microscopy show contrasting results in a study of phytoplankton occurrence in a freshwater environment. PloS One 9: e106510. DOI: 10.1371/journal.pone.0106510.

Zielinski O., Braun A., Henkel R., Mascarenhas V.J., Meier D. \& Voß D. 2018. Physical oceanography during Maria S. Merian cruise MSM65 (GREENHAB II). Institute for Chemistry and Biology of the Marine Environment, Carl-von-Ossietzky University of Oldenburg, Germany. PANGAEA. DOI: 10.1594/PANGAEA.886181. 